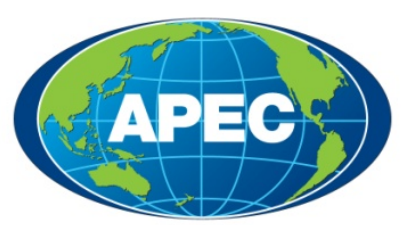

Asia-Pacific

Economic Cooperation

\title{
Assessment of Biomass Resources from Marginal Lands in APEC Economies
}

\section{Energy Working Group}

August 2009 
This report was prepared for the APEC Energy Working Group under EWG 11/2008A by:

Anelia Milbrandt

National Renewable Energy Laboratory (NREL)

Golden, Colorado, USA

Web site: www.nrel.gov

Dr. Ralph P. Overend

NREL Research Fellow (Retired)

Ottawa, Ontario, Canada

APEC\#209-RE-01.4 


\section{Acknowledgments}

The authors would like to acknowledge and thank the project overseer, Mr. Jeffrey Skeer (Department of Energy, USA and chair of the APEC Biofuels Task Force), for his support, review, and guidance throughout this project. We also thank Mr. Mark Stumborg from Agriculture and Agri-Food Canada for his review and recommendations. 


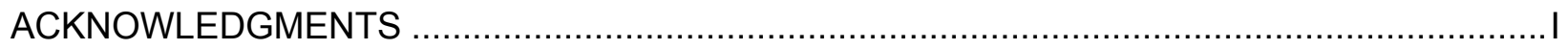

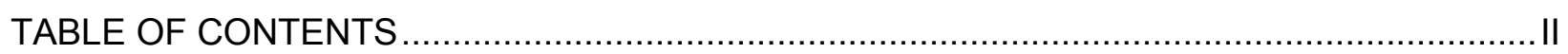

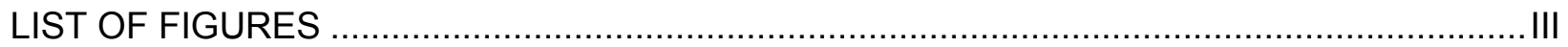

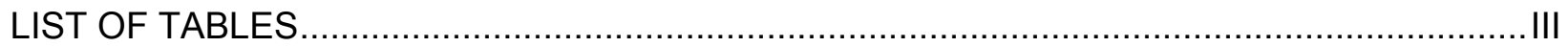

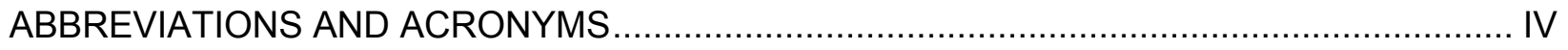

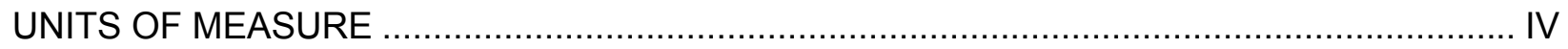

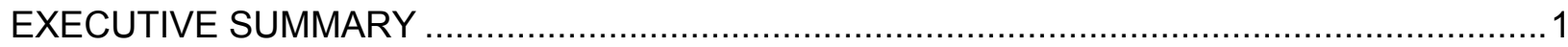

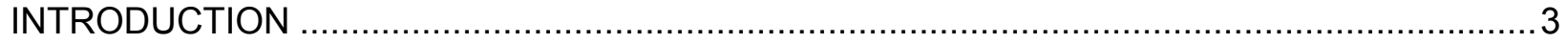

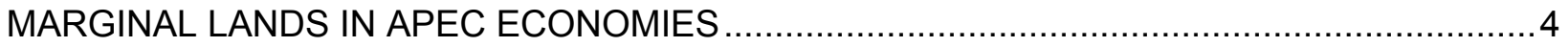

BIOMASS POTENTIAL ON MARGINAL LANDS IN APEC ECONOMIES …..........................

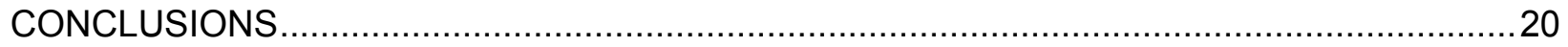

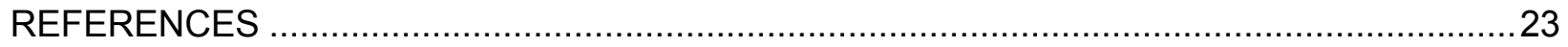

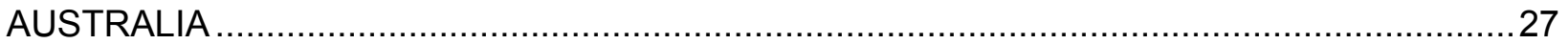

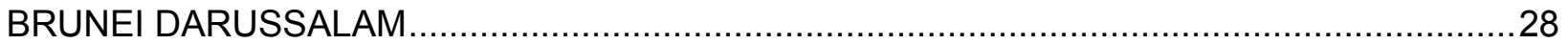

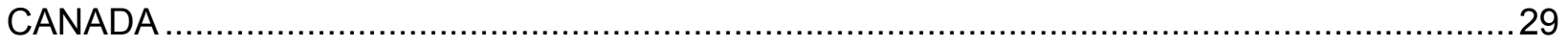

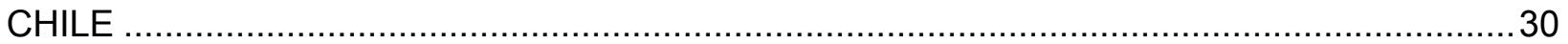

CHINA .

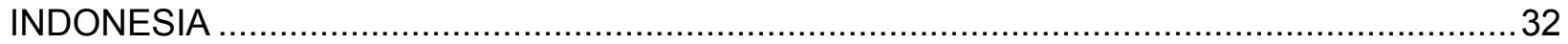

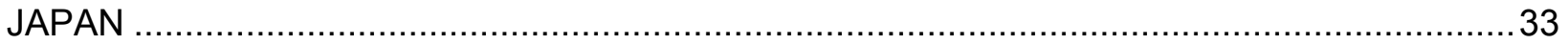

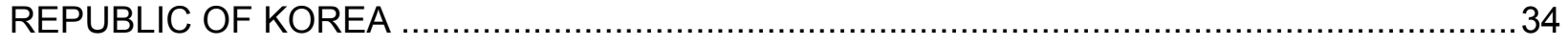

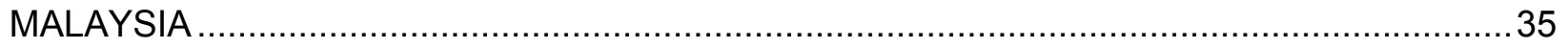

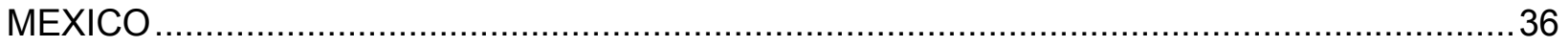

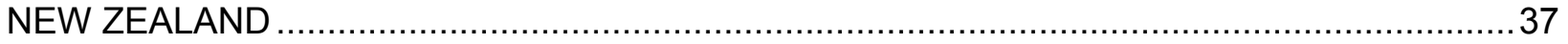

PAPUA NEW GUINEA

PERU …1-1.

PHILIPPINES

RUSSIA

CHINESE TAIPEI

THAILAND ……

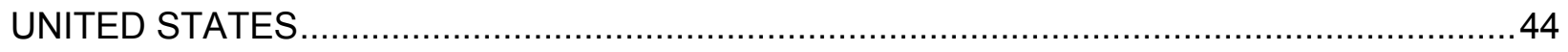

VIET NAM 


\section{List of Figures}

Figure 1 Methodology for Assessing Available Marginal Lands in APEC Economies ................ 5

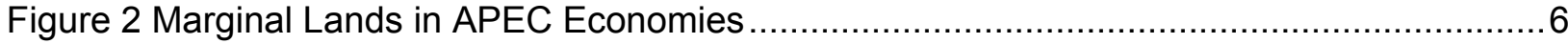

Figure 3 General Outline of Crop Production Modeling ....................................................12

Figure 4 Annual Net Primary Productivity on Marginal Lands in APEC Economies ..................16

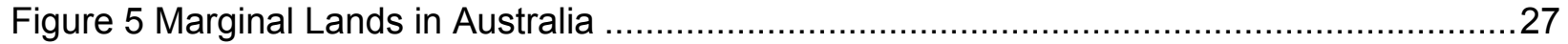

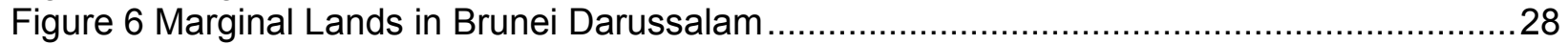

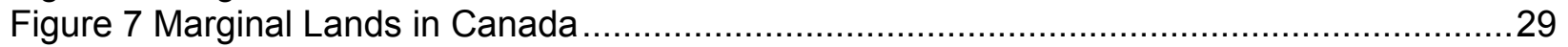

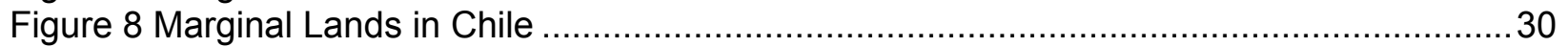

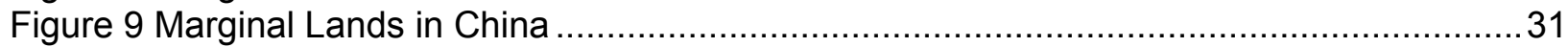

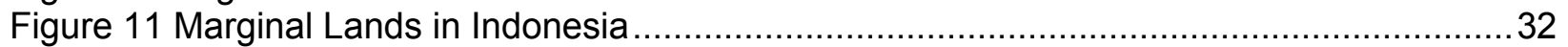

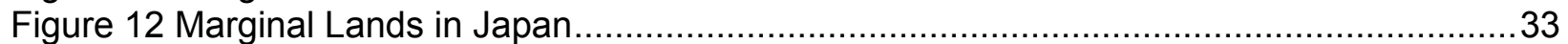

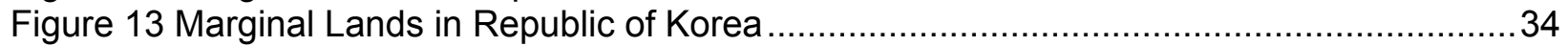

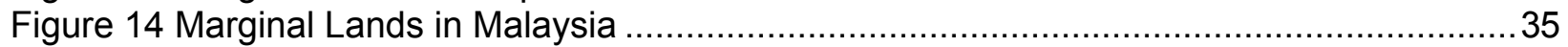

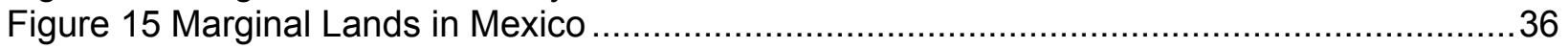

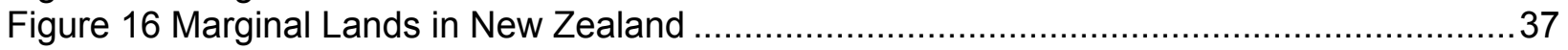

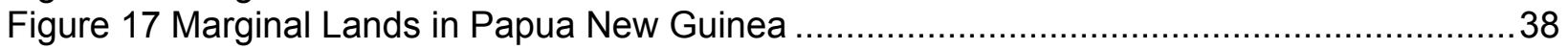

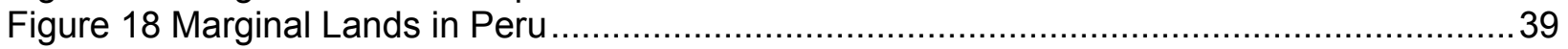

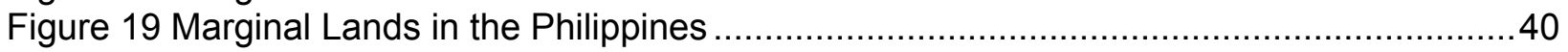

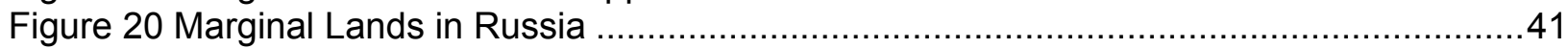

Figure 10 Marginal Lands in Chinese Taipei .................................................................. 42

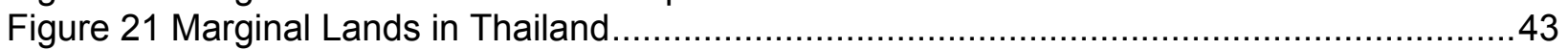

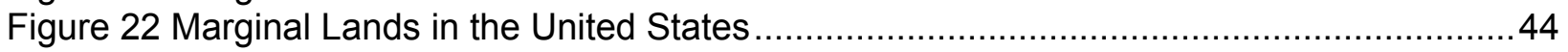

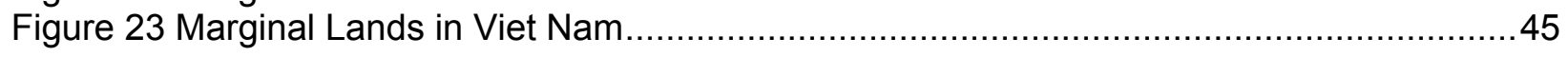

\section{List of Tables}

Table 1 Marginal Lands in APEC Economies Part 1 of 2 .................................................. 7

Table 2 Marginal Lands in APEC Economies Part 2 of 2 ................................................. 7

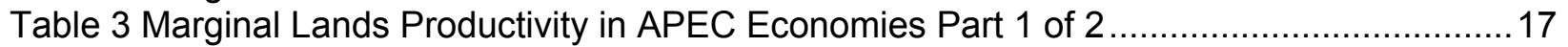

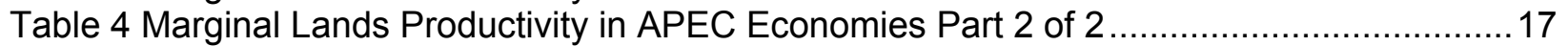

Table 5 Average Biofuels Potential on Marginal Lands in APEC Economies .......................... 18

Table 7 Ethanol Potential from Marginal Lands, Share of Current Gasoline Consumption and Crude Oil Import in APEC Economies ...........................................................................25

Table 8 Ethanol Potential from Existing Biomass Resources, Share of Current Gasoline

Consumption and Crude Oil Import in APEC Economies ..................................................26 


\section{Abbreviations and Acronyms}

APEC - Asia-Pacific Economic Cooperation

$\mathrm{CO}_{2}-$ Carbon Dioxide

ENSO - El Nino Southern Oscillation

FAO - Food and Agriculture Organization

GAEZ - Global Agro-Ecological Zones

GHG - Greenhouse gases

GIS - geographic information system

IIASA - International Institute for Applied Systems Analysis

NPP - Net Primary Productivity

NREL - National Renewable Energy Laboratory (of the U.S. Department of Energy)

PNG - Papua New Guinea

$\mathrm{RS}$ - remote sensing

UNEP - United Nations Environmental Programme

USDA - United States Department of Agriculture

\section{Units of Measure}

g-gram

Gt - Gigatonne $\left(10^{9}\right.$ tonne)

ha - hectare

$\mathrm{hm}^{3}$ - cubic hectometer or $1,000,000 \mathrm{~m}^{3}$ or $10^{9} \mathrm{~L}$, described in some sources as a GL

(Gigaliter)

$\mathrm{m}^{2}$ - square meter

$\mathrm{m}^{3}$ - cubic meter

MJ - Megajoule ( $10^{6}$ joule)

Mt - Megatonne (10 6 tonne)

$\mathrm{km}^{2}$ - square kilometer

Tonne ( $\mathrm{t}$ ) - metric ton 


\section{Executive Summary}

Marginal lands have received an increased attention by the bioenergy industry as an alternative to cropland for feedstock supply that could help to address the food vs. fuel debate challenging the industry's further development. Literature suggests that Asia-Pacific Economic Cooperation (APEC) economies have vast marginal lands available, which may hold potential for the production of biofuels feedstock. However, the term "marginal land" has been used quite loosely without a concrete definition. Moreover, in many economies, the extent and characteristics of these lands have not been systematically assessed, nor has their suitability for biofuels crop production been evaluated.

The goal of this study is to examine the marginal lands in APEC economies and evaluate their biomass productivity potential. Twelve categories of marginal lands are identified using the Global Agro-Ecological Zones system of the United Nations Food and Agriculture Organization. Numerous exclusions are applied using state-of-the-art geographic information systems (GIS) to estimate the available marginal lands in APEC economies. The analysis estimates that about 4 million $\mathrm{km}^{2}$ (400 million ha) of marginal lands are available in the APEC region, representing $6.5 \%$ of the total land area. Economies with the largest marginal lands include Australia (13.5\% of total land area); Canada (4\%); China (5\%); Russia (2\%); and the United States (13\%).

The study's biomass production assessment methodology takes into account a combination of the current vegetation cover and a calculation of the net primary productivity (NPP). The NPP incorporates a fixed middle range of radiation use efficiency and adjusts for air temperature. It is derived from extensive data sets and translated into the annual yield of a lignocellulosic biomass, typical of grasses such as switchgrass and other thin-stemmed perennials or thickstemmed grasses in tropical areas. Other lignocellulosics that would be similar are short-rotation tree species with willow and poplar as examples in temperate regions and eucalyptus in more tropical environments. These crop types meet the criteria of non-edible crops and will give the highest biomass potential.

This study estimates the total annual biomass resource potential on marginal lands in APEC economies to be about $1.3 \mathrm{Gt}$, which converts roughly into $540 \mathrm{hm}^{3}$ of ethanol fuel or $260 \mathrm{Mt}$ of gasoline equivalent. By comparison, APEC uses about $621 \mathrm{Mt}$ of gasoline and crude oil import 
is about $1.3 \mathrm{Gt}$ annually (IEA 2006). So the ethanol potential from marginal lands could displace two-fifths of the region's gasoline consumption and one-fifth of its crude oil imports.

Many economies could substitute a substantial volume of their current gasoline consumption and crude oil imports with ethanol from marginal lands, as illustrated in the Appendix. These include Australia; Chile; New Zealand; Peru; and Viet Nam. But there could be technical or economic restrictions on the use of these lands, which suggests that only a portion of this potential can be realized. This portion would be different in each economy and could be determined by a detailed techno-economic feasibility assessment, which is beyond the scope of this study.

Previous work by the authors (Milbrandt, A., Overend, R. 2008) evaluated the ethanol potential from existing lignocellulosic biomass (primarily crop and forest residues) in the APEC region. That study estimated a similar volume of ethanol potential, $509 \mathrm{hm}^{3}$ of ethanol fuel or $245 \mathrm{Mt}$ of gasoline equivalent, enough to displace two-fifths of the region's gasoline consumption and onefifth of its crude oil import. Comparing the results from both studies at an economy level, it appears that some economies (such as China; Indonesia; Japan; Korea; Malaysia; the Philippines; Thailand; and Viet Nam) have large biomass potential from farm and forest residues, but limited potential from marginal lands (Appendix Tables 7 and 8). Other economies (Australia; Canada; Chile; Mexico; New Zealand; Russia; and United States) have major production potential on marginal lands as well as from residues. A combination of feedstocklignocellulosic biomass from residues and biomass grown on marginal lands-would assure a sustainable resource supply for biofuels production in these economies. Such a supply could substantially displace current import and consumption of petroleum products.

The present study evaluates only the ethanol potential on marginal lands. Biodiesel could present very good opportunities for some of these lands in tropical regions, so future work should evaluate the biodiesel potential on marginal lands in APEC economies and compare it with the results from the previous study. More detailed assessments at a sub-regional or an economy level, and a finer than $100 \mathrm{~km}^{2}$ spatial resolution, would also provide a better understanding of the biofuels potential on marginal lands in the APEC region. Given that the interest in biofuels is in large part driven by greenhouse gas mitigation policies, it would seem reasonable that future work be linked to climate modeling, which is now starting to have the ability to predict regional changes. 


\section{Introduction}

Land is a precious commodity and more so today in the light of dynamic land use and land cover change driven by economic, environmental, social, and political factors. Availability of land to supply the emerging biofuels industry with enough biomass is a challenge shared by all APEC economies. In addition, the use of conventional crops for biofuels production has recently been of concern because they can compete with food materials. These considerations have encouraged the APEC economies to search for an alternative approach to biofuels feedstock supply-growing non-edible crops on marginal lands. Using these lands to grow energy crops, even though the lands are less productive, can provide some additional environmental and social benefits, including restoration of degraded land, carbon sequestration, and job creation.

Literature suggests that APEC economies have vast marginal lands available, which may hold potential for the production of biofuels feedstock. However, the term "marginal land" has been used quite loosely without a concrete definition. Moreover, in many economies, the extent and characteristics of marginal lands have not been systematically assessed, and their suitability for biofuels crop production has not been evaluated.

The goal of this study is to assess the biomass resource potential on marginal lands in the APEC region. To achieve this goal, the following two project objectives were defined:

1. Identify available marginal lands in the APEC economies and

2. Evaluate their biomass production potential.

To accomplish the first objective, the project utilizes state of the art geographic information systems (GIS) technology-a computer-based information technology used to create, manipulate, analyze, and visualize geographic information. To accomplish the second objective, the study uses a crop production model that considers various inputs to simulate plant development.

This study intends to provide policy makers and industry developers with a general understanding of the biofuels potential on marginal lands in the APEC economies. It also aims to outline steps for further, more detailed analysis to guide their future strategic decisions. 


\section{Marginal Lands in APEC Economies}

\section{Definition of Marginal Lands}

Marginal lands are characterized by poor climate, poor physical characteristics, or difficult cultivation. They include areas with limited rainfall, extreme temperatures, low quality soil, steep terrain, or other problems for agriculture. Examples include deserts, high mountains, land affected by salinity, waterlogged or marshy land, barren rocky areas, and glacial areas. Evidently, not all of these areas are suitable for agriculture. The authors evaluated various marginal land categories and identified the following as suitable for this study:

- Bare and herbaceous areas (not in use or with only moderately intensive pastoralism). Lands with intensive and extensive pastoralism are not included.

- Lands with moderate (8-16\%) and steep (16-30\%) slope.

- Lands with soil problems:

- Shallow soils (depth $<50 \mathrm{~cm}$ )

- Poorly and imperfectly drained soils

- Soils with low to moderate natural fertility

- Coarse textured or sandy soils (Arenosols, Regosols, and Vitric Andosols with coarse texture, and all soils with petric and stony phase)

- Soils with heavy cracking clays (Vertisols and vertic sub-groups)

- Salt-affected soils (Solonchaks, Solonetz, and Solodic Planosols)

- Soils with gypsic horizon ${ }^{1}$ (Gypsic Xerosols and Gypsic Yermosols)

- Acid soils [pH is strongly (5.5 - 4.5) to extremely acid (<4.5)]

- Soils with high calcium level or Calcisols

- Peat soils (Histosols).

\section{Data Information}

Most of the marginal lands data for this study were obtained in a geospatial format from the Global Agro-Ecological Zones (GAEZ) system. The GAEZ program was developed by the Food and Agriculture Organization of the United Nations (FAO) and the International Institute for Applied Systems Analysis (IIASA). GAEZ evaluates climatic parameters, topography, soil, and land cover to estimate crop suitability and land productivity potentials for each 5-minutelatitude/longitude grid-cell (roughly each $10 \mathrm{~km} \times 10 \mathrm{~km}$ or $100 \mathrm{~km}^{2}$ of land area) for the whole

\footnotetext{
${ }^{1}$ Gypsic soils are soils that contain sufficient quantities of gypsum (calcium sulphate).
} 
world. This study uses soil constraints, climatic constraints, and topography datasets from GAEZ. Land use and dominant soils data (with the same spatial resolution of $100 \mathrm{~km}^{2}$ ), as well as railroads and wetlands data, came from FAO's GeoNetwork, a geospatial data clearinghouse. Several datasets, such as Calcisols and land stress data, were provided by the United States Department of Agriculture. Data on protected areas were extracted from the World Database on Protected Areas, a joint product of the United Nations Environmental Program and the International Union for Conservation of Nature. Some reference data layers (administrative boundaries, cities, etc.) were obtained from the Environmental Systems Research Institute, while others (roads) were gathered from the Digital Chart of the World 19911992.

\section{Analytic Methodology}

To assess the available marginal lands in the APEC region, land use/cover and environmental exclusions have to be applied. These are areas where no conventional agriculture for food crops is recommended or possible. GIS technology is particularly useful for this type of analysis, considering the various tools it offers to support it. These tools include spatial overlay, intersection of data layers, and elimination of certain features. The marginal lands data were incorporated into the GIS system for spatial manipulation and analysis. The methodology for assessing the available marginal lands in APEC economies, using GIS, is illustrated in Figure 1.

\section{All Marginal Lands}

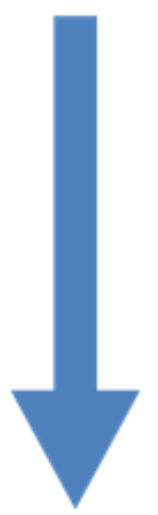

Available Marginal Lands
1. Start with all marginal lands (in some areas there is an overlap of different categories)

2. Exclude deserts, cold regions, and ice/glacier areas

3. Exclude protected areas

4. Exclude water features (lakes, wetlands, swamps)

5. Exclude forests, agricultural lands, urban areas, herbaceous and bare lands under intensive and extensive pastoralism

Figure 1 Methodology for Assessing Available Marginal Lands in APEC Economies 
The results of this analysis are presented in both graphic and tabular format (Figure 2 and Table 1-2). The study estimates the available marginal lands in APEC economies at about 4 million $\mathrm{km}^{2}$ or $6.5 \%$ of total land area. Economies with the largest total share of marginal lands include United States (13\% of total land area); Australia (13.5\%); China (5\%); Canada (4\%); and Russia $(2 \%)$. Hong Kong and Singapore economies were excluded from this study due to their predominantly urban landscape, which would not be able to support crop development.

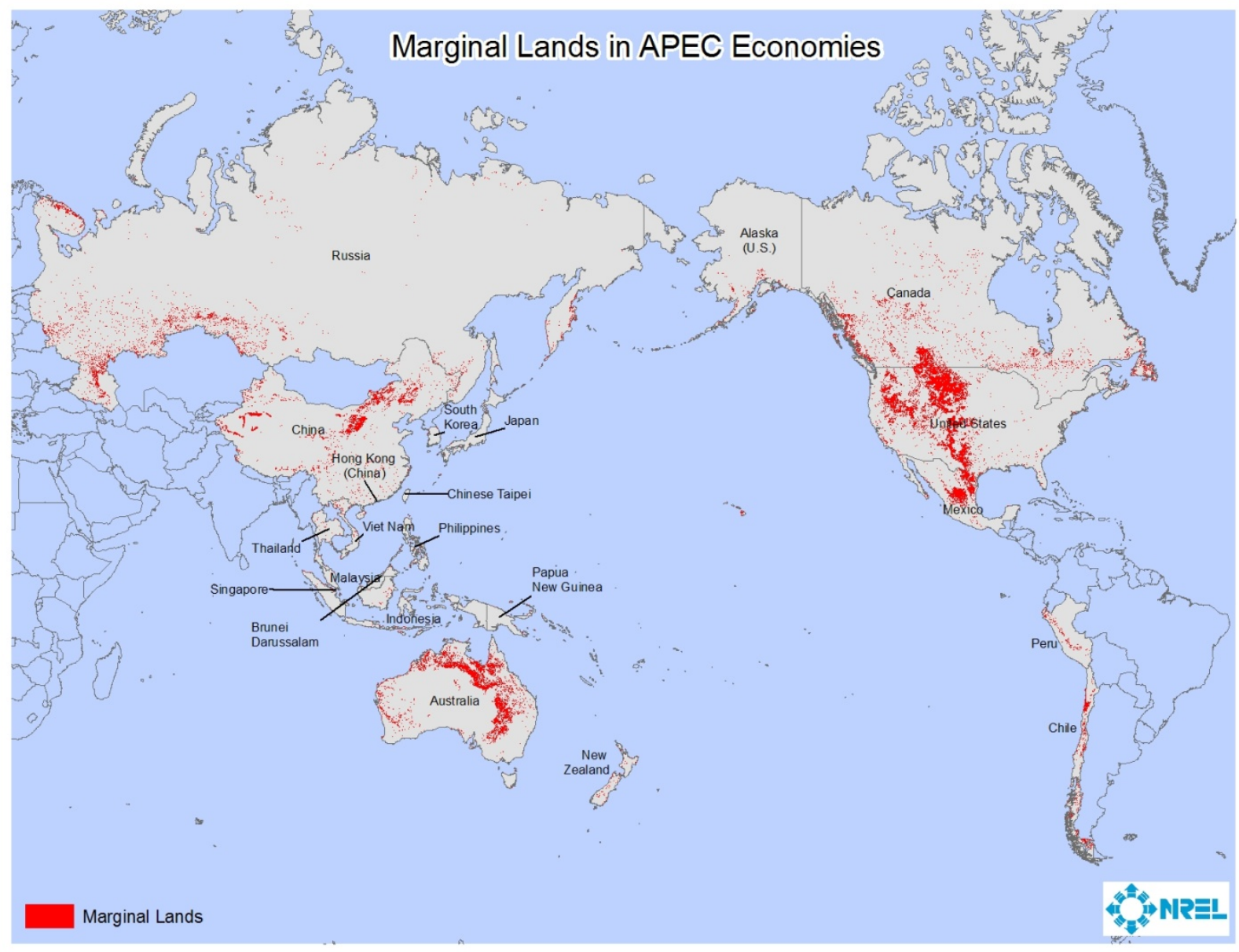

Figure 2 Marginal Lands in APEC Economies 
Table 1 Marginal Lands in APEC Economies Part 1 of 2

\begin{tabular}{|c|c|c|c|c|c|c|c|c|c|c|c|c|c|c|}
\hline \multirow[t]{2}{*}{ Economy } & \multirow[t]{2}{*}{$\begin{array}{l}\text { Total Land } \\
\text { Area }\left(\mathrm{km}^{2}\right)\end{array}$} & \multirow[t]{2}{*}{$\begin{array}{l}\text { Population } \\
2007\end{array}$} & \multicolumn{2}{|c|}{$\begin{array}{l}\text { Soils with High } \mathrm{Ca} \\
\text { Level (Calcids) }\end{array}$} & \multicolumn{2}{|c|}{$\begin{array}{l}\text { Soils with Heavy } \\
\text { Cracking Clays }\end{array}$} & \multicolumn{2}{|c|}{ Shallow Soils } & \multicolumn{2}{|c|}{$\begin{array}{c}\text { Poorly and } \\
\text { Imperfectly Drained } \\
\text { Soils } \\
\end{array}$} & \multicolumn{2}{|c|}{$\begin{array}{c}\text { Soils with Low to } \\
\text { Moderate Natural } \\
\text { Fertility }\end{array}$} & \multicolumn{2}{|c|}{$\begin{array}{c}\text { Soils with Gypsic } \\
\text { Horizon }\end{array}$} \\
\hline & & & $\mathbf{k m}^{2}$ & $\%$ & $\mathrm{~km}^{2}$ & $\%$ & $\mathrm{~km}^{2}$ & $\%$ & $\mathrm{~km}^{2}$ & $\%$ & $\mathbf{k m}^{2}$ & $\%$ & $\mathbf{k m}^{2}$ & $\%$ \\
\hline Australia & $7,694,273$ & $20,434,176$ & 70,928 & 0.9 & 250,966 & 3.3 & 147,240 & 1.9 & 77,473 & 1.0 & 377,322 & 4.9 & 0 & 0 \\
\hline Brunei & 6,078 & 386,511 & 0 & 0 & 0 & 0 & 0 & 0 & 0 & 0 & 39 & 0.6 & 0 & 0 \\
\hline Canada & $9,832,884$ & $33,390,141$ & 0 & 0 & 0 & 0 & 41,540 & 0.4 & 17,770 & 0.2 & 94,930 & 1.0 & 0 & 0 \\
\hline Chile & 722,511 & $16,284,741$ & 34 & 0.005 & 71 & 0.01 & 38,684 & 5.4 & 990 & 0.1 & 52,119 & 7.2 & 0 & 0 \\
\hline China & $9,402,887$ & $1,321,851,888$ & 7,697 & 0.1 & 1,761 & 0.02 & 107,439 & 1.1 & 59,571 & 0.6 & 210,604 & 2.2 & 1,243 & 0.01 \\
\hline Indonesia & $1,847,033$ & $234,693,997$ & 0 & 0 & 742 & 0.04 & 2,274 & 0.1 & 2,565 & 0.1 & 28,447 & 1.5 & 0 & 0 \\
\hline Japan & 370,727 & $127,467,972$ & 0 & 0 & 0 & 0 & 19 & 0.01 & 668 & 0.2 & 3,349 & 0.9 & 0 & 0 \\
\hline Korea & 94,773 & $49,044,790$ & 0 & 0 & 0 & 0 & 0 & 0 & 251 & 0.3 & 791 & 0.8 & 0 & 0 \\
\hline Malaysia & 328,536 & $24,821,286$ & 0 & 0 & 0 & 0 & 53 & 0.02 & 291 & 0.1 & 2,449 & 0.7 & 0 & 0 \\
\hline Mexico & $1,953,851$ & $108,700,891$ & 22,739 & 1.2 & 35,344 & 1.8 & 129,414 & 6.6 & 3,633 & 0.2 & 49,685 & 2.5 & 0 & 0 \\
\hline New Zealand & 267,214 & $4,115,771$ & 0 & 0 & 0 & 0 & 150 & 0.1 & 1,162 & 0.4 & 12,174 & 4.6 & 0 & 0 \\
\hline PNG & 458,666 & $5,795,887$ & 0 & 0 & 0 & 0 & 543 & 0.1 & 138 & 0.03 & 4,739 & 1.0 & 0 & 0 \\
\hline Peru & $1,296,605$ & $28,674,757$ & 0 & 0 & 1,776 & 0.1 & 26,373 & 2.0 & 2,729 & 0.2 & 33,038 & 2.5 & 0 & 0 \\
\hline Philippines & 280,958 & $91,077,287$ & 0 & 0 & 246 & 0.1 & 0 & 0 & 465 & 0.2 & 2,199 & 0.8 & 0 & 0 \\
\hline Russia & $16,897,294$ & $141,377,752$ & 0 & 0 & 0 & 0 & 6,516 & 0.04 & 28,451 & 0.2 & 116,349 & 0.7 & 0 & 0 \\
\hline Chinese Taipei & 35,980 & $22,858,872$ & 0 & 0 & 0.007 & 0.00 & 355 & 1.0 & 250 & 0.7 & 236 & 0.7 & 0 & 0 \\
\hline Thailand & 515,357 & $65,068,149$ & 0 & 0 & 0 & 0 & 6,052 & 1.2 & 2,231 & 0.4 & 16,066 & 3.1 & 0 & 0 \\
\hline United States & $9,426,295$ & $301,139,947$ & 18,771 & 0.2 & 22,118 & 0.2 & 77,612 & 0.8 & 20,510 & 0.2 & 98,960 & 1.0 & 0 & 0 \\
\hline Viet Nam & 322,743 & $85,262,356$ & 0 & 0 & 232 & 0.1 & 11,056 & 3.4 & 645 & 0.2 & 19,226 & 6.0 & 0 & 0 \\
\hline Total & $61,754,665$ & $2,682,447,171$ & 120,169 & 0.2 & 313,256 & 0.5 & 595,319 & 1.0 & 219,792 & 0.4 & $1,122,724$ & 1.8 & 1,243 & 0.002 \\
\hline
\end{tabular}

Table 2 Marginal Lands in APEC Economies Part 2 of 2

\begin{tabular}{|c|c|c|c|c|c|c|c|c|c|c|c|c|c|c|c|c|}
\hline \multirow[t]{2}{*}{ Economy } & \multirow[t]{2}{*}{$\begin{array}{l}\text { Total Land } \\
\text { Area }\left(\mathrm{km}^{2}\right)\end{array}$} & \multirow[t]{2}{*}{$\begin{array}{l}\text { Population } \\
2007\end{array}$} & \multicolumn{2}{|c|}{ Histosols } & \multicolumn{2}{|c|}{ Salt-affected Soils } & \multicolumn{2}{|c|}{ Acid Soils } & \multicolumn{2}{|c|}{$\begin{array}{l}\text { Coarse-textured } \\
\text { Soils or Sandy Soils }\end{array}$} & \multicolumn{2}{|c|}{$\begin{array}{c}\text { Lands with } \\
\text { Moderate and } \\
\text { Steep Slopes }\end{array}$} & \multicolumn{2}{|c|}{$\begin{array}{l}\text { Select Land Use } \\
\text { Categories }\end{array}$} & \multicolumn{2}{|c|}{$\begin{array}{l}\text { Total Marginal } \\
\text { Lands }\end{array}$} \\
\hline & & & $\mathrm{km}^{2}$ & $\%$ & $\mathrm{~km}^{2}$ & $\%$ & $\mathrm{~km}^{2}$ & $\%$ & $\mathrm{~km}^{2}$ & $\%$ & $\mathbf{k m}^{2}$ & $\%$ & $\mathrm{~km}^{2}$ & $\%$ & $\mathbf{k m}^{2}$ & $\%$ \\
\hline Australia & $7,694,273$ & $20,434,176$ & 0 & 0 & 580,712 & 7.5 & 29,255 & 0.4 & 114,506 & 1.5 & 31,907 & 0.4 & $1,024,020$ & 13.3 & $1,036,239$ & 13.5 \\
\hline Brunei & 6,078 & 386,511 & 0.18 & 0.003 & 1 & 0.01 & 28 & 0.5 & 0 & 0 & 0 & 0 & 39 & 0.6 & 85 & 1.4 \\
\hline Canada & $9,832,884$ & $33,390,141$ & 27,625 & 0.3 & 20,546 & 0.2 & 208,606 & 2.1 & 6,546 & 0.07 & 91,550 & 0.9 & 368,550 & 3.7 & 376,092 & 3.8 \\
\hline Chile & 722,511 & $16,284,741$ & 490 & 0.1 & 4,609 & 0.6 & 12,234 & 1.7 & 1,047 & 0.1 & 41,562 & 5.8 & 91,191 & 12.6 & 95,645 & 13.2 \\
\hline China & $9,402,887$ & $1,321,851,888$ & 939 & 0.01 & 72,859 & 0.8 & 143,893 & 1.5 & 0 & 0 & 207,575 & 2.2 & 507,174 & 5.4 & 511,905 & 5.4 \\
\hline Indonesia & $1,847,033$ & $234,693,997$ & 3,397 & 0.2 & 270 & 0.01 & 19,057 & 1.0 & 3,086 & 0.2 & 14,247 & 0.8 & 17,548 & 1.0 & 37,123 & 2.0 \\
\hline Japan & 370,727 & $127,467,972$ & 0 & 0 & 0 & 0 & 1,889 & 0.5 & 0 & 0 & 3,331 & 0.9 & 93 & 0.03 & 4,878 & 1.3 \\
\hline Korea & 94,773 & $49,044,790$ & 0 & 0 & 0 & 0 & 632 & 0.7 & 0 & 0 & 902 & 1.0 & 263 & 0.3 & 1,651 & 1.7 \\
\hline Malaysia & 328,536 & $24,821,286$ & 686 & 0.2 & 968 & 0.3 & 1,737 & 0.5 & 113 & 0.03 & 1,204 & 0.4 & 828 & 0.3 & 3,534 & 1.1 \\
\hline Mexico & $1,953,851$ & $108,700,891$ & 0 & 0 & 76,789 & 3.9 & 902 & 0.0 & 18,771 & 1.0 & 134,347 & 6.9 & 252,140 & 12.9 & 255,862 & 13.1 \\
\hline New Zealand & 267,214 & $4,115,771$ & 24 & 0.01 & 58 & 0.02 & 4,161 & 1.6 & 1,112 & 0.4 & 7,474 & 2.8 & 13,315 & 5.0 & 17,299 & 6.5 \\
\hline PNG & 458,666 & $5,795,887$ & 229 & 0.05 & 30 & 0.01 & 426 & 0.1 & 0 & 0 & 3,875 & 0.8 & 103 & 0.02 & 7,123 & 1.6 \\
\hline Peru & $1,296,605$ & $28,674,757$ & 0 & 0 & 1,660 & 0.1 & 4,447 & 0.3 & 8,508 & 0.7 & 16,638 & 1.3 & 56,810 & 4.4 & 57,029 & 4.4 \\
\hline Philippines & 280,958 & $91,077,287$ & 0 & 0 & 303 & 0.1 & 2,536 & 0.9 & 35 & 0.01 & 4,122 & 1.5 & 864 & 0.3 & 6,357 & 2.3 \\
\hline Russia & $16,897,294$ & $141,377,752$ & 13,849 & 0.1 & 47,339 & 0.3 & 52,187 & 0.3 & 1,881 & 0.01 & 99,485 & 0.6 & 361,173 & 2.1 & 369,176 & 2.2 \\
\hline Chinese Taipei & 35,980 & $22,858,872$ & 0 & 0 & 94 & 0.3 & 250 & 0.7 & 0 & 0 & 54 & 0.1 & 316 & 0.9 & 693 & 1.9 \\
\hline Thailand & 515,357 & $65,068,149$ & 0.05 & 0.00 & 289 & 0.1 & 14,904 & 2.9 & 320 & 0.06 & 8,177 & 1.6 & 15,893 & 3.1 & 17,253 & 3.3 \\
\hline United States & $9,426,295$ & $301,139,947$ & 962 & 0.01 & 424,042 & 4.5 & 39,258 & 0.4 & 206,941 & 2.2 & 659,996 & 7.0 & $1,207,300$ & 12.8 & $1,214,007$ & 12.9 \\
\hline Viet Nam & 322,743 & $85,262,356$ & 0.05 & 0.00 & 299 & 0.1 & 18,020 & 5.6 & 400 & 0.1 & 8,729 & 2.7 & 19,432 & 6.0 & 21,090 & 6.5 \\
\hline Total & $61,754,665$ & $2,682,447,171$ & 48,201 & 0.1 & $1,230,868$ & 2.0 & 554,423 & 0.9 & 363,265 & 0.6 & $1,335,174$ & 2.2 & $3,937,054$ & 6.4 & $4,033,039$ & 6.5 \\
\hline
\end{tabular}

Select land use categories include bare and herbaceous areas (not in use or with only moderately intensive pastoralism). It doesn't include lands with intensive and extensive pastoralism. Total marginal lands don't correspond to the sum of all categories due to geographic overlap among land types. 


\section{Biomass Potential on Marginal Lands in APEC Economies}

The prediction of crop yields in farm systems and of the net rate of carbon fixation by the biosphere has become very important as humanity attempts to balance the needs of society against the maintenance of the ecosystems that support life on the planet. Using the benefits of crop growth simulation and GIS techniques, this study estimates the potential yield of energy crops on marginal lands that are either abandoned or not used in mainstream agriculture, due to either economic or environmental challenges.

Crop yields have been estimated for the last 50 years, though significant advances did not really appear until the widespread availability of satellite sensor data after the 1970s. The initial estimation methods grew out of the development of crop growth models, which attempted to relate plant physiology to the seasonal growing conditions and the optimization of the growth parameters. Major contributions to this field were made at the University of Wageningen in the Netherlands. There, in the 1970s, Professor C.T. de Wit established academic courses addressing both simulation techniques and the mechanisms of crop physiology (Goudriaan, J. and H. H. van Laar 1994).

At the time, simulation techniques were in their infancy, but crop physiology had by then established the major features of the control of plant yield. In order of importance, these are (1) the energy input determined by both the supply of solar radiation and the radiation use efficiency (RUE), (2) water availability, measured by water vapor pressure which is a product of the physics of water transport in the plant and the nature of the stomatal openings ${ }^{2}$ in the leaf that let $\mathrm{CO}_{2}$ in, and (3) nutrient availability, especially nitrogen, which is needed to produce the nucleic acids, DNA and protein of the plant and its seeds.

The RUE is typically $1-2 \mathrm{~g}$ of dry matter production per MJ of light intercepted. If the plant has an extensive area of leaf coverage, i.e. a Leaf Area Index (LAI) of $4 \mathrm{~m}^{2}$ of leaf surface per $\mathrm{m}^{2}$ of land area, the daily dry matter accumulation at $12 \mathrm{MJ} / \mathrm{m}^{2}$ irradiation will be about $20 \mathrm{~g} / \mathrm{m}^{2} /$ day. Over a 100 day growing season at this rate, the harvestable above-ground biomass will be 20 $\mathrm{t} / \mathrm{ha}\left(20 \mathrm{~g} / \mathrm{m}^{2} /\right.$ day $\left.\times 100 \times 10^{4} \mathrm{~m}^{2} / \mathrm{ha} \times 10^{-6} \mathrm{t} / \mathrm{g}\right)$. This assumes that there is no water deficit or

\footnotetext{
${ }^{2}$ In botany, a stoma is a pore, found in the leaf and stem epidermis that is used for gas exchange.
} 
nutrient limitation. At around $500+\mathrm{mm}$ of water per year evenly distributed in the growing season, this is usually the case.

In parallel with the work on crop growth simulation and with fundamental studies in photosynthesis, the International Geophysical Year of 1965 saw the first integrated perspectives on how the entire biosphere interacts with the atmosphere and indirectly with the oceans through the carbon dioxide $\left(\mathrm{CO}_{2}\right)$ cycle. This work also became more important as there was growing awareness of how changes in the greenhouse gases (GHG) levels in the atmosphere were likely to alter the climate. The climate work of course is focused on the two most important GHG ( $\mathrm{CO}_{2}$ and water vapor) and their interaction with the biosphere with respect to the net flow of carbon from the atmosphere to the plant biomass and the stability of these processes with respect to maintaining the atmosphere in equilibrium. Climate modeling increased the investment in this area significantly and the high priority of the topic led to the addition of much more detailed mapping and the application of GIS to interpret the data.

The energy crops of the future are not yet known. There is a general concern that the use of food crops could conflict with the supply of food and animal feed for the growing human population. It is also recognized that crops for energy may have to meet more stringent sustainability criteria than existing food and feed crops. Obviously both the food and the energy crop systems have to be sustainable. However, there is already a burden of proof in some jurisdictions that energy crop systems should be capable of offsetting fossil carbon emissions by more than half. Criteria for sustainable carbon offset are being developed by the U.S. Environmental Protection Agency and required by Directive 2009/28/EC of the European Parliament.

Carbon displacement and net energy efficiency are measured using the tools of life cycle assessment (LCA) in what are often described as well-to-wheel (WTW) analyses. Because energy crops are used for heat, combined heat and power (CHP), electricity, and synthetic natural gas (SNG), as well as liquid fuels for transportation, this project uses the results from full LCA, rather than just WTW analysis, to describe the assessment of the energy crop cycles in determining the optimum crop and product strategy.

LCA has identified several important criteria for an energy crop. Perhaps the most basic criterion is that the energy yield has to be high (i.e. the solar energy captured in the biomass 
has to be maximized). Obviously the harvested energy crop obviously has to have characteristics that are suitable for the envisioned end use. For thermal energy applications, the maximum yield criterion suggests that lignocellulosics such as wood and herbaceous species would give the highest yield, as these are closest in chemical composition to the photosynthate produced in the leaf and thus minimize transformation losses inside the growing grass or tree species. For liquid transportation biofuels, volumetric energy density is important. Such fuels as ethanol and biodiesel are more reduced than the simple photosynthate, and there is competition between plants that naturally produce hydrocarbons such as waxes, lipids, or triacylglycerides (TAG) and the use of industrial processes in chemical plants or biorefineries to convert lignocellulosics, starches, and sugars into the final product. LCAs also suggest that the plants should be perennials to avoid the energy and material costs of an annual cycle of tillage, planting (of seeds or cuttings), tending, and harvesting. Likewise, the issue of tillage and the loss of soil carbon is an important criterion in crop evaluation.

Another important criterion is the issue of land use change (LUC), which has two facets that are called direct and indirect. Direct LUC is the change in status of the area that was previously in either a crop or abandoned land, to an energy crop. The other concern is of indirect LUC as it is argued that increasing land in energy crops will require that food cultivation will have to be increased elsewhere, either by converting other land into agricultural (food) production, intensifying existing land use for food, or reducing human food consumption. The measurement of indirect LUC is complex and is being strongly debated. At a minimum understanding, this issue will require complex economic models of world food production linked to the energy system.

Land clearing and preparation for planting, as well as tillage, will cause carbon fixed in the soil to be released, possibly creating a deficit in carbon balance that will need to be repaid by the fossil energy displacement of the energy crop in order for biofuels production to be environmentally sustainable. This deficit can be just one year or less for the cultivation of marginal lands, as well as for most cropland under cultivation and for many types of grassland. But it is substantially greater, typically in the order of a few decades, when woody savanna or secondary or degraded forest is involved, and it can range up to several centuries for most tropical forest or even several millennia for tropical peat forest. Hence, the development of energy crops on marginal lands, provided that they are reasonably productive, has a major 
advantage over development of these crops on croplands from the standpoint of carbon impacts of direct land use change.

A number of candidate energy crops are being tested around the world. Many are lignocellulosic crops including tree species such as poplar, willow, and eucalyptus and herbaceous crops such as switchgrass and Miscanthus. Oil bearing shrubs and trees such as Jatropha Curcas and Pongamia are examples of in planta biochemical conversions to biofuel precursors as their seeds provide TAG for processing into diesel fuels such as fatty acid methyl esters or renewable diesel.

Because of the diversity of potential energy crops and their evolving sustainability criteria, we have chosen to provide an estimate of the productivity of potential bioenergy crop lands in terms of the annual Net Primary Productivity or NPP. Readers can then choose their own crop and factor in its allocation of NPP carbon into the energy crop product that they need- be it branches and above ground stem for lignocellulosic or the TAG yield for an oil crop. The annual NPP values are a valuable indicator of the optimum locations within the available land classes for further investigation.

In order to explain the process used, we will first discuss crop modeling as this is the foundation of estimating the NPP. We will then explain how we have brought into the NPP assessment the GIS information on actual vegetation cover status to more accurately reflect the actual site potential.

\section{Plant Growth Modeling}

The seminal work of the University of Wageningen has been widely adopted around the world in crop production modeling, and a relatively simple model SUCROS is described below that elucidates how crop modeling proceeds. The general outline of SUCROS-like models is illustrated in Figure 3. Flows of energy and material (solid lines with arrows) as well as control signals (dotted) are illustrated. 


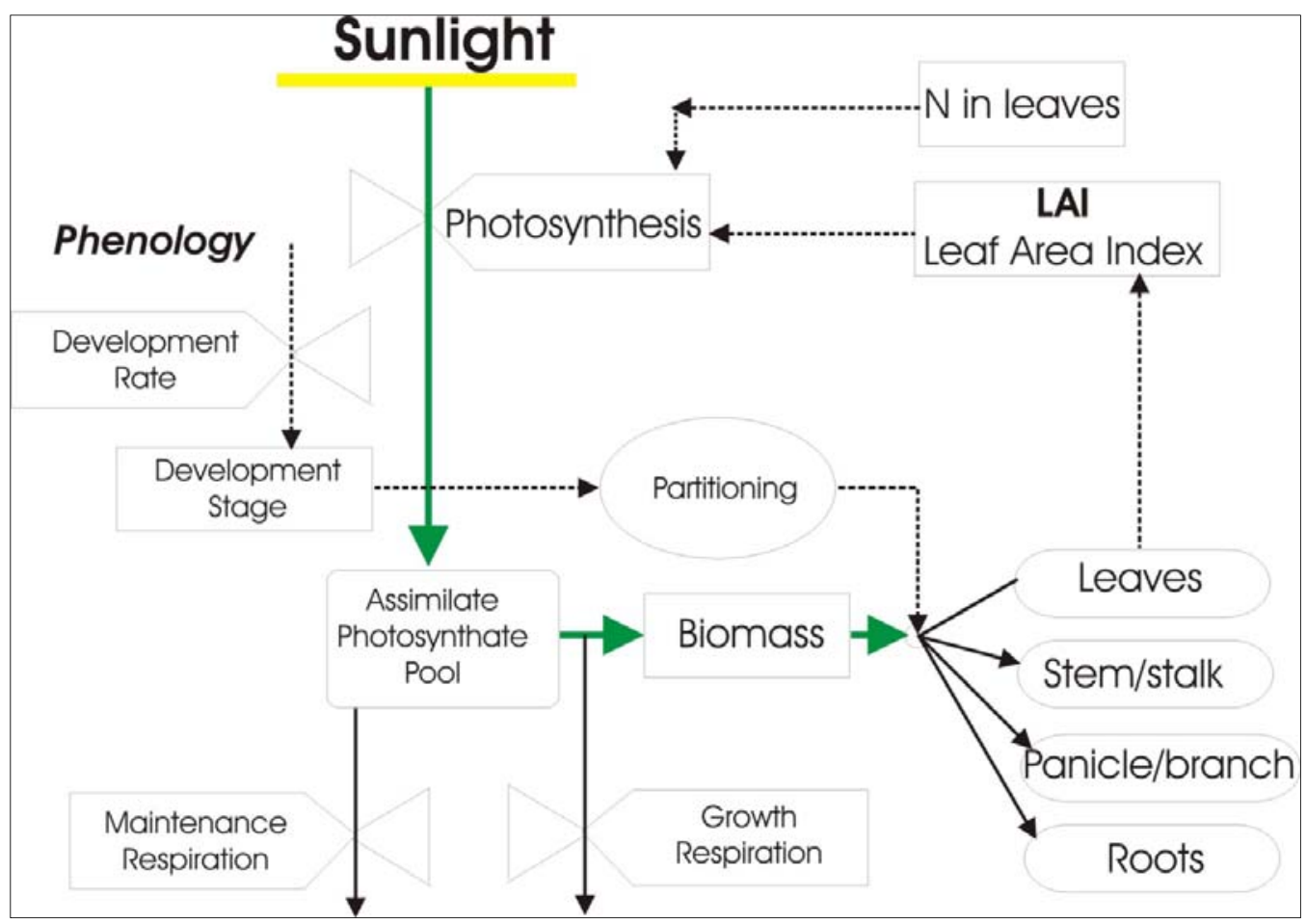

Figure 3 General Outline of Crop Production Modeling

The key physiological inputs required for the simulation of crop growth, such as Leaf Area Index, are available for many crop species. The crop growth pattern is called the phenology of the plant and identifies the different stages of growth pattern with energy and time input over the growing season. Time and energy are interlinked and the phenology in the field can be tracked against daily heat units, a crude measure of the average daily temperature. For example, to produce a mature winter wheat variety, about 2,200 daily heat units are required. This means that it would take 147 calendar days to produce a winter wheat crop if the average daily temperature was a constant $15^{\circ} \mathrm{C}$. In the early stages, the plant develops leaves and more stems (tillers). As the leaves develop, more energy is intercepted and the wheat moves through to so-called boot development, which leads to flowering and then the filling of the grain.

The other part of SUCROS is the incorporation of actual weather data for the growing site. This determines the energy input as solar energy on an hourly and daily basis which is then used to calculate the assimilation of $\mathrm{CO}_{2}$. The assimilated $\mathrm{CO}_{2}$ is then passed as photosynthate to carbohydrate production (photosynthate $=\mathrm{CH}_{2} \mathrm{O}$, the monomer of carbohydrates), which in turn passes into a module for dry matter partitioning between the various plant components. Part of the photosynthate is consumed in "powering" the growth and transport processes. This is called 
maintenance respiration. This factor is very temperature-dependent and accounts for the poor performance of plant species at high temperatures.

The descendents of SUCROS for the estimation of crop yields then require extensive weather data records for the solar input, temperature, and rainfall. They also require knowledge of the soil properties, particularly with respect to water-holding properties. And, as described above, they require a detailed phenological ${ }^{3}$ development of the chosen species/cultivar. Such process models have been extensively developed for U.S. agriculture. These models are currently in their third decade. CENTURY (and its sibling DayCent, a daily version) originated at the Colorado State University's Natural Resources Ecology Laboratory in the 1980s with National Science Foundation funding and U.S. Department of Agriculture support. Many versions later, William J. Parton continues to lead its development into the biogeochemical behavior of carbon, nitrogen, phosphorus and sulphur in the arable crop environment, as well as grasslands, savanna, and forests. The European model WOFOST is a direct descendent of SUCROS and has been further developed by the Joint Research Centre of the European Commission to predict current annual crop yields and compare them with historical data to determine trends related to climate change. Information on these and many more models can be found on the Register of Ecological Models maintained by Ecobas.org.

As the need for modeling has moved away from crops about which detailed phenology is available and into regions of the world without detailed time series weather data, the general principles described above have been adapted. In some instances, the need to grow known crops in new locations has been met by means of synthetic climate generators. Given some inputs and possibly GIS data obtained by Satellite, stochastic time series can be generated for a given location for input into the models. Likewise, the all important solar input can now be calculated at any point on the surface of the globe using tools developed by the U.S. National Aeronautics and Space Administration and the U.S. Department of Energy's National Renewable Energy Laboratory.

We have chosen to use data generated by a combined model by VITO (Flemish Institute for Technological Research). This model is primarily based on radiation with satellite sensor data for the fraction of the photosynthetically active radiation (PAR) absorbed at a given location. The

\footnotetext{
${ }^{3}$ Phenology is the scientific study of periodic biological phenomena, such as flowering, breeding, and migration, in relation to climatic conditions.
} 
model is used with SPOT satellite images and National Oceanic and Atmospheric Administration data at a $1 \mathrm{~km}^{2}$ pixel resolution to provide 10 day average values of NPP starting on the $1^{\text {st }}, 10^{\text {th }}$, and $21^{\text {st }}$ day of each month. To generate the NPP for an entire year, the 36 sets of data are combined to give an annual value. The process used calculates three values:

Gross Primary Productivity: GPPd $=$ fAPARd.$\varepsilon \cdot \mathrm{CO}_{2}$ fert. pa $(T d) \cdot c . S g d$

Net Primary Productivity: NPPd $=$ GPPd. $(1-\mathrm{Ad})$

Net Ecosystem Productivity: NEPd $=$ NPPd - Rd $=$ NPPd $-k y \cdot p h(T d)$

In Equation 1, the daily flux of carbon captured by photosynthesis in $\mathrm{g} / \mathrm{m}^{2} /$ day is based on the Montief method, developed by Phillippe Montief in the late 1880s. Sgd is the daily incoming global solar radiation ( $\mathrm{MJ} / \mathrm{m}^{2} /$ day) calculated from a solar irradiance model. This is multiplied by "c," a factor of 0.48 which is the fixed proportion of PAR between $400-700 \mathrm{~nm}$. GPP is also dependent on the air temperature (average daily value $\mathrm{Td}$ ), a non-linear effect captured by the term pa $(T d)$. The $\mathrm{CO}_{2}$ fertilization factor, $\mathrm{CO}_{2}$ fert, computes the effect of the increasing $\mathrm{CO}_{2}$ levels on the performance of the enzyme Rubisco which captures the $\mathrm{CO}_{2}$ in the plant leaf. fAPARd is the fraction of PAR captured in the canopy, which is based on the relation between this and the Normalized Difference Vegetation Index (NDVI) derived from the satellite based remote sensing. The term $\varepsilon$ is the previously described radiation use efficiency (RUE) which is fixed in this model as $1.1 \mathrm{~g}$ of carbon mass in biomass per MJ of insolation.

Equation 2 calculates NPP by adjusting for the respiration that takes place in the plant and returns carbon to the atmosphere. This is portrayed in the model by a linear dependence on the air temperature (Veroustraete F. and Sabbe H. 2000).

We do not use the third equation in this study, as it concerns the annual carbon flux and calculates the return of carbon from the soil at the end of the growing cycle. Clearly this is important in the calculation of the carbon flux from the atmosphere to the ecosystems of the world. In our case, however, the key carbon flux is the harvest of biomass for use as either bioenergy or as feedstock for the production of biofuels.

NPP as carbon uptake on an annual basis was measured for the growth year 1999-2000 at a spatial resolution of $100 \mathrm{~km}^{2}$ grid-cell using GeoSuccess data (VITO 2009). Data for the Northern Hemisphere were for the calendar year 1999, while those for the Southern Hemisphere were 
taken from June 1999 through May 2000. Ideally, the average of several years should be taken into account, but for this project it was only possible to take this single annual snapshot.

The marginal lands' productivity in APEC economies is illustrated in Figure 4. The range of NPP values run from zero (no carbon capture) to values greater than $20 \mathrm{t} / \mathrm{ha} / \mathrm{yr}$. As can be seen, the marginal lands in APEC economies have low productivity. The predominant NPP value is less than $6 \mathrm{t} / \mathrm{ha} / \mathrm{yr}$. The values are indicative in that they are a single value shown at a $100 \mathrm{~km}^{2}$ gridcell for the terrestrial carbon flux as NPP. An additional uncertainty is that the data are calculated for a RUE of $1.1 \mathrm{~g} / \mathrm{MJ}$. Plant breeding has improved this value to almost $2 \mathrm{~g} / \mathrm{MJ}$ in crops such as sugarcane growing under high-input irrigated conditions, but such conditions might not be typical on marginal lands (Sinclair, T.R., Muchow, R.C.1999).

The results are presented in terms of the mass of carbon fixed by the plants. However, biomass can also be estimated in terms of harvestable above-ground lignocellulosics. This is done by multiplying the carbon value by 1.25-going from carbon to lignocellulosic mass-and assuming that one third of the biomass is below ground and non recoverable ${ }^{4}$. Tables 3 and 4 present the biomass resource potential on marginal lands in APEC economies, as well as the associated biofuels potential. The NPP values are aggregated to country level using standard GIS techniques, considering the marginal land hectares in each $100 \mathrm{~km}^{2}$ cell and the NPP per hectare associated with individual cells. Economies with the highest biomass resource potential include Australia; United States; Russia; China; and Canada due to their large marginal land areas. But such economies vary significantly in terms of their biomass yield per unit of area and thus in the portion of the potential that can be practically obtained.

\footnotetext{
4 NPP measured as carbon includes both above- and below-ground biomass. We assumed from the literature that the aboveground is $2 / 3$ of the total carbon fixed. The chemical formula of lignocellulosic biomass, averaged across many species, is somewhere around $\mathrm{CH}^{1.4} \mathrm{O}^{0.56}$. In other words, 1.4 hydrogen atoms (with a mass of 1 ) and 0.56 oxygen atoms (with a mass of 16 ) for each atom of carbon (with a mass of 12). Therefore, the total molecular weight of a typical lignocellulosic feedstock, relative to an atom of carbon, is $(1.4 \times 1+0.56 \times 16+1 \times 12) / 12$ or about $22.5 / 12$ or 1.88 . Multiplying this ratio of lignocellulose to carbon, 1.88 , by the portion of carbon above ground, $2 / 3$, we find that the ratio of lignocellulose to total carbon is $1.88 \times 2 / 3=1.25$
} 


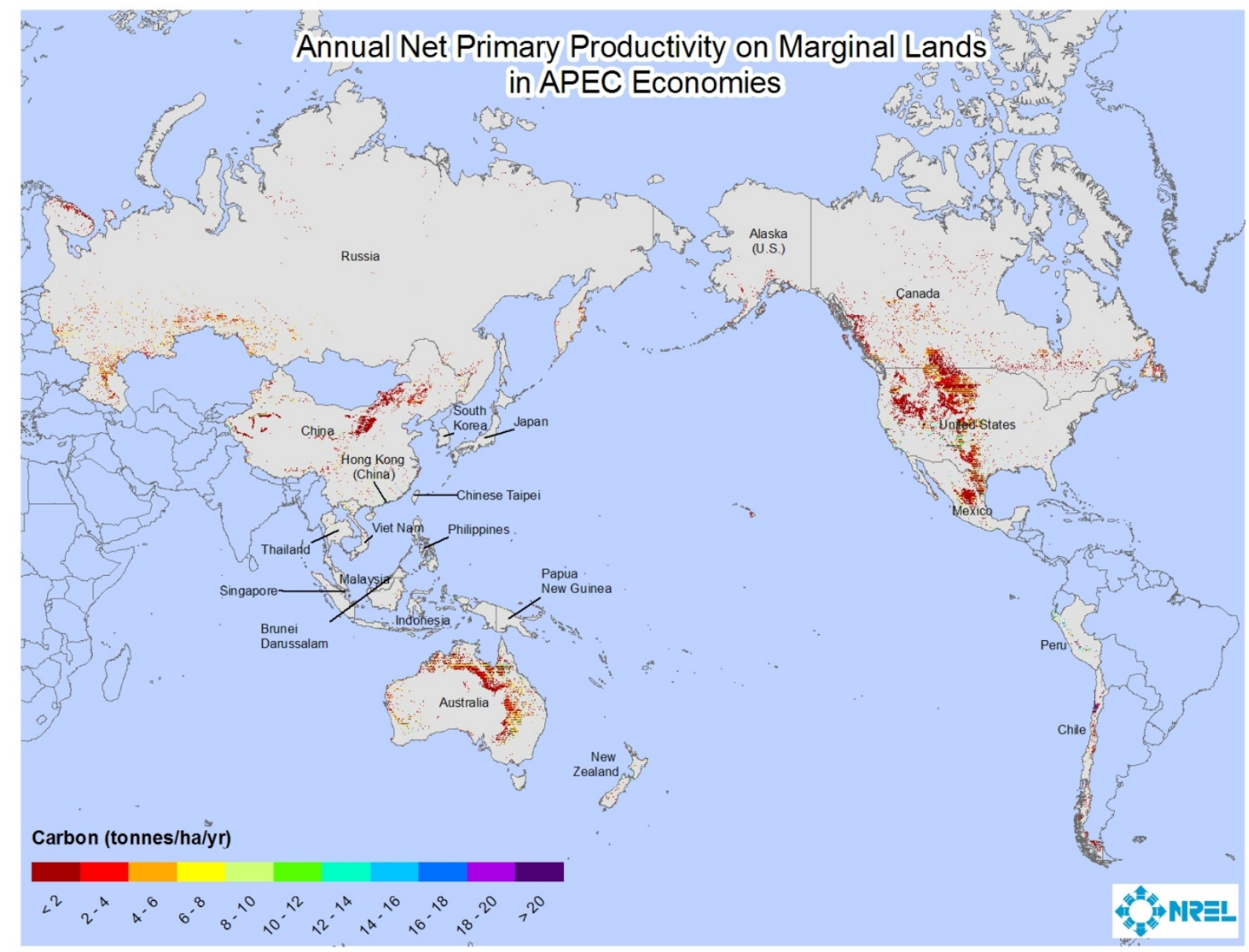

Figure 4 Annual Net Primary Productivity on Marginal Lands in APEC Economies

IIASA, in their studies of the European land potential, have classified area yields of biomass as follows: Very Suitable (VS) 13 - 17 t/ha; Suitable (S) $10-13$ t/ha; Moderately Suitable (MS) 7 10 t/ha; marginally suitable (ms) 3-5 t/ha; and Not Suitable (NS) less than 2 t/ha. The classification incorporates economic principles that relate to harvesting effort and the necessary radius of collection, as the harvested areas increase rapidly with decreasing productivity and suitability classification. The gold standard, which energy crops such as switchgrass or tree species are hoped to reach, has already been demonstrated in trials with yields of $23-27 \mathrm{t} / \mathrm{ha}$ of lignocellulosic biomass on good land with adequate rainfall and a long growing season (BRDB 2008). 
Table 3 Marginal Lands Productivity in APEC Economies Part 1 of 2

\begin{tabular}{|c|c|c|c|c|c|c|c|c|c|c|c|c|c|c|c|c|c|c|c|c|c|c|c|c|}
\hline \multirow{2}{*}{ Economy } & \multicolumn{4}{|c|}{ Soils with High $\mathrm{Ca}$ Level (Calcids) } & \multicolumn{4}{|c|}{ Soils with Heavy Cracking Clays } & \multicolumn{4}{|c|}{ Shallow Soils } & \multicolumn{4}{|c|}{ Poorly and Imperfectly Drained Soils } & \multicolumn{4}{|c|}{ Soils with Low to Moderate Natural Fertility } & \multicolumn{4}{|c|}{ Soils with Gypsic Horizon } \\
\hline & $\mathrm{km}^{2}$ & $\begin{array}{c}\text { NPP } \\
\text { (tonne/yr) } \\
\end{array}$ & $\begin{array}{c}\begin{array}{c}\text { Biomass } \\
\text { (tonne/yr) }\end{array} \\
\end{array}$ & $\begin{array}{l}\text { Biofuels } \\
\left(\mathrm{hm}^{3}\right)\end{array}$ & $\mathbf{k m}^{2}$ & $\begin{array}{c}\text { NPP } \\
\text { (tonnes/yr) }\end{array}$ & \begin{tabular}{|c|}
$\begin{array}{c}\text { Biomass } \\
\text { (tonnes/yr) }\end{array}$ \\
\end{tabular} & $\begin{array}{c}\text { Biofuels } \\
\left(\mathrm{hm}^{3}\right)\end{array} \mid$ & $\mathrm{km}^{2}$ & $\begin{array}{c}\text { NPP } \\
\text { (tonnes/yr) } \\
\end{array}$ & \begin{tabular}{|c|}
$\begin{array}{c}\text { Biomass } \\
\text { (tonnes/yr) }\end{array}$ \\
\end{tabular} & \begin{tabular}{|c} 
Biofuels \\
$\left(\mathrm{hm}^{3}\right)$
\end{tabular} & $\mathrm{km}^{2}$ & \begin{tabular}{|c|} 
NPP \\
(tonnes/yr)
\end{tabular} & \begin{tabular}{|c|c}
$\begin{array}{c}\text { Biomass } \\
\text { (tonnes/yr) }\end{array}$ \\
\end{tabular} & $\begin{array}{c}\text { Biofuels } \\
\left(\mathrm{hm}^{3}\right)\end{array}$ & $\mathrm{km}^{2}$ & \begin{tabular}{|c|} 
NPP \\
(tonnes/yr)
\end{tabular} & $\begin{array}{c}\text { Biomass } \\
\text { (tonnes/yr) }\end{array}$ & $\begin{array}{c}\text { Biofuels } \\
\left(\mathrm{hm}^{3}\right)\end{array} \mid$ & $\mathrm{km}^{2}$ & \begin{tabular}{|c|} 
NPP \\
(tonnes/yr)
\end{tabular} & \begin{tabular}{|c|c}
$\begin{array}{c}\text { Biomass } \\
\text { (tonnes/yr) }\end{array}$ \\
\end{tabular} & \begin{tabular}{|c} 
Biofuels \\
$\left(\mathrm{hm}^{3}\right)$
\end{tabular} \\
\hline Australia & 70,928 & $21,792,987$ & $27,328,405$ & 10.7 & 250,966 & \begin{tabular}{|l|}
$57,299,465$ \\
\end{tabular} & \begin{tabular}{|l|}
$71,853,529$ \\
\end{tabular} & \begin{tabular}{|r|}
28.2 \\
\end{tabular} & 147,240 & $41,625,810$ & $52,198,765$ & 20.5 & 77,473 & $27,336,623$ & $34,280,125$ & 13.5 & 377,322 & $119,636,665$ & $150,024,378$ & 59.0 & 0 & 0 & 0 & \\
\hline Brunei & 0 & 0 & 0 & 0 & 0 & 0 & 0 & 0 & 0 & 0 & 0 & 0 & 0 & & 0 & 0 & 39 & 8,529 & 10,695 & 0.004 & 0 & 0 & 0 & \\
\hline Canada & 0 & 0 & 0 & 0 & 0 & 0 & 0 & 0 & 41,540 & $8,968,876$ & \begin{tabular}{|l|}
$11,246,971$ \\
\end{tabular} & 4.4 & 17,770 & $4,664,255$ & $5,848,976$ & 2.3 & 94,930 & $22,928,849$ & $28,752,777$ & 11.3 & 0 & 0 & 0 & \\
\hline Chile & 34 & 3,613 & 4,531 & 0.002 & 71 & 64,694 & 81,126 & 0.0 & 38,684 & $12,221,208$ & \begin{tabular}{|r|}
$15,325,395$ \\
\end{tabular} & 6.0 & 990 & 85,258 & 106,914 & 0.04 & 52,119 & $16,186,530$ & $20,297,908$ & 8.0 & 0 & 0 & 0 & \\
\hline China & 7,697 & 57,863 & 72,560 & 0.029 & 1,761 & 701,211 & 879,318 & 0.3 & 107,439 & $26,007,893$ & \begin{tabular}{|r|}
$32,613,898$ \\
\end{tabular} & 12.8 & 59,571 & \begin{tabular}{|l|}
$12,362,702$ \\
\end{tabular} & $15,502,829$ & 6.1 & 210,604 & \begin{tabular}{|r|}
$49,639,536$ \\
\end{tabular} & $62,247,978$ & 24.5 & 1,243 & 66,976 & 83,987 & 0.03 \\
\hline Indonesia & 0 & 0 & 0 & 0 & 742 & 166,053 & 208,231 & 0.1 & 2,274 & 670,079 & 840,279 & 0.3 & 2,565 & \begin{tabular}{|r|}
$1,049,924$ \\
\end{tabular} & $\begin{array}{r}1,316,605 \\
\end{array}$ & 0.5 & 28,447 & \begin{tabular}{|r|}
$9,561,810$ \\
\end{tabular} & $11,990,510$ & 4.7 & 0 & 0 & 0 & \\
\hline Japan & 0 & 0 & 0 & 0 & & 0 & 0 & 0 & 19 & 15,101 & \begin{tabular}{|l|}
18,937 \\
\end{tabular} & 0.007 & $\begin{aligned} 668 \\
\end{aligned}$ & 148,812 & \begin{tabular}{|l|}
186,610 \\
\end{tabular} & 0.1 & 3,349 & $1,142,390$ & $1,432,558$ & 0.6 & 0 & 0 & 0 & \\
\hline Korea & 0 & 0 & 0 & 0 & 0 & 0 & 0 & 0 & 0 & 0 & 0 & 0 & 251 & 63,007 & 79,011 & 0.03 & 791 & 221,956 & 278,333 & 0.1 & 0 & 0 & 0 & \\
\hline Malaysia & 0 & 0 & 0 & 0 & 0 & 0 & 0 & 0 & 53 & 865 & 1,085 & 0.0004 & 291 & 13,255 & 16,621 & 0.01 & 2,449 & 689,762 & $\begin{array}{l}864,962 \\
\end{array}$ & 0.3 & 0 & 0 & 0 & \\
\hline Mexico & 22,739 & $2,068,538$ & $2,593,946$ & 1.019 & 35,344 & $\begin{array}{l}9,479,353 \\
9\end{array}$ & \begin{tabular}{|l|}
$11,887,109$ \\
\end{tabular} & 4.7 & \begin{tabular}{|l|l|}
129,414 \\
\end{tabular} & $28,089,120$ & \begin{tabular}{|r|}
$35,223,756$ \\
\end{tabular} & 13.8 & 3,633 & 811,148 & $1,017,179$ & 0.4 & 49,685 & \begin{tabular}{|l|}
$16,055,320$ \\
\end{tabular} & $20,133,371$ & 7.9 & 0 & 0 & 0 & \\
\hline New Zealand & 0 & 0 & 0 & 0 & 0 & 0 & 0 & 0 & 150 & 74,958 & 93,997 & 0.04 & 1,162 & 455,045 & 570,626 & 0.2 & 12,174 & $5,452,492$ & $6,837,425$ & 2.7 & 0 & 0 & 0 & \\
\hline PNG & 0 & 0 & 0 & 0 & 0 & \begin{tabular}{l|l}
0 \\
\end{tabular} & 0 & 0 & 543 & 81,021 & 101,600 & 0.04 & 138 & & 0 & 0 & 4,739 & 826,008 & $1,035,814$ & 0.4 & 0 & 0 & 0 & \\
\hline Peru & 0 & 0 & 0 & 0 & 1,776 & $2,114,334$ & $2,651,375$ & 1.0 & 26,373 & $21,116,598$ & \begin{tabular}{|r|}
$26,480,213$ \\
\end{tabular} & 10.4 & 2,729 & $2,478,509$ & $3,108,050$ & 1.2 & 33,038 & \begin{tabular}{|r|}
$27,413,672$ \\
\end{tabular} & \begin{tabular}{|l|}
$34,376,745$ \\
\end{tabular} & 13.5 & 0 & 0 & 0 & \\
\hline Philippines & 0 & 0 & 0 & 0 & 246 & 192 & 241 & 0.0 & 0 & 0 & \begin{tabular}{|r|}
0 \\
\end{tabular} & 0 & 465 & 51 & 64 & 0.0 & 2,199 & \begin{tabular}{|r|}
468,360 \\
\end{tabular} & $\begin{array}{l}587,324 \\
\end{array}$ & 0.2 & 0 & 0 & 0 & \\
\hline Russia & 0 & 0 & 0 & 0 & 0 & 0 & 0 & 0 & 6,516 & $2,034,340$ & \begin{tabular}{|l|l|}
$2,551,062$ \\
\end{tabular} & 1.0 & 28,451 & $8,802,016$ & \begin{tabular}{|l|}
$11,037,728$ \\
\end{tabular} & 4.3 & 116,349 & \begin{tabular}{|l|}
$40,282,191$ \\
\end{tabular} & \begin{tabular}{|l|}
$50,513,868$ \\
\end{tabular} & 19.8 & 0 & 0 & 0 & \\
\hline Chinese Taipei & 0 & 0 & 0 & 0 & 0.007 & 8 & 10 & 0.0 & 355 & \begin{tabular}{|l|}
376,145 \\
\end{tabular} & \begin{tabular}{|l|l|}
471,685 \\
\end{tabular} & 0.2 & 250 & \begin{tabular}{|l|}
48,467 \\
\end{tabular} & 60,778 & 0.02 & 236 & \begin{tabular}{|r|}
143,914 \\
\end{tabular} & 180,469 & 0.1 & 0 & 0 & 0 & \\
\hline Thailand & 0 & 0 & 0 & 0 & 0 & 0 & & 0 & 6,052 & \begin{tabular}{|l|l|}
$2,692,007$ \\
\end{tabular} & $3,375,777$ & 1.3 & 2,231 & $1,132,567$ & $1,420,240$ & 0.6 & 16,066 & $7,696,834$ & $9,651,830$ & 3.8 & 0 & 0 & 0 & \\
\hline United States & 18,771 & $4,238,290$ & $5,314,815$ & 2.088 & 22,118 & $6,197,593$ & $7,771,781$ & 3.1 & 77,612 & $24,623,345$ & \begin{tabular}{|l|}
$30,877,675$ \\
\end{tabular} & 12.1 & 20,510 & $6,306,651$ & $7,908,541$ & 3.1 & 98,960 & $32,557,662$ & $40,827,308$ & 16.0 & 0 & 0 & 0 & \\
\hline Viet Nam & & 0 & 0 & & 232 & $\begin{array}{r}60,100 \\
\end{array}$ & 75,365 & 0.0 & 11,056 & $5,471,106$ & \begin{tabular}{|r|}
$6,860,767$ \\
\end{tabular} & $\begin{array}{l}2.7 \\
\end{array}$ & 645 & \begin{tabular}{|l|}
228,157 \\
\end{tabular} & 286,109 & 0.1 & \begin{tabular}{l|l}
19,226 \\
\end{tabular} & \begin{tabular}{|l|}
$8,566,362$ \\
\end{tabular} & $\begin{array}{l}10,742,218 \\
\end{array}$ & $\begin{array}{l}4.2 \\
\end{array}$ & 0 & 0 & 0 & \\
\hline Total & 120,169 & $28,161,291$ & \begin{tabular}{|l|}
$35,314,258$ \\
\end{tabular} & 13.877 & 313,256 & \begin{tabular}{|l|}
$76,083,003$ \\
\end{tabular} & \begin{tabular}{|l|}
$95,408,085$ \\
\end{tabular} & 37.5 & 595,319 & \begin{tabular}{|l|l|}
$174,068,471$ \\
\end{tabular} & \begin{tabular}{|l|}
$218,281,863$ \\
\end{tabular} & 85.8 & 219,792 & \begin{tabular}{|l|}
$65,986,448$ \\
\end{tabular} & $82,747,005$ & 32.5 & $1,122,724$ & \begin{tabular}{|l|}
$359,478,845$ \\
\end{tabular} & \begin{tabular}{|l|}
$450,786,471$ \\
\end{tabular} & 1777.1. & 1,243 & 66,976 & 83,987 & 0.03 \\
\hline
\end{tabular}

Table 4 Marginal Lands Productivity in APEC Economies Part 2 of 2

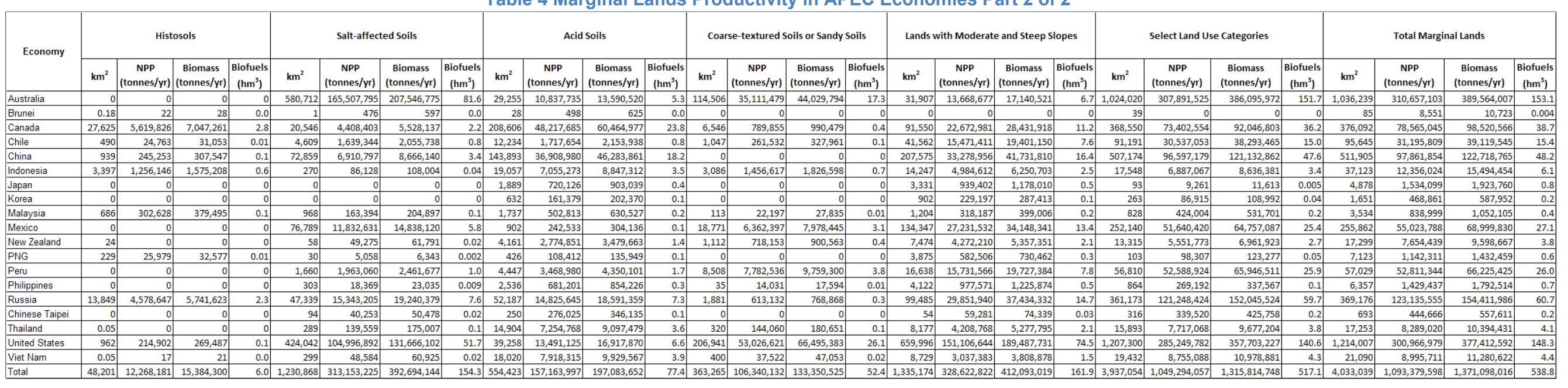

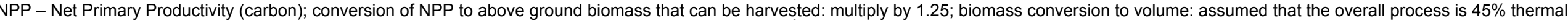
efficiency to an ethanol liquid fuel with an energy density of $27 \mathrm{MJ} / \mathrm{kg}$ and a physical density of $789 \mathrm{~kg} \mathrm{~m}^{3}$ 
Taking the average productivity across the entire individual APEC economy, while ignoring possible hot spots of better potential, and applying IIASA's classification of land suitability described above, Table 5 illustrates that marginal lands are indeed marginal with respect to biofuels feedstock potential.

Table 5 Average Biofuels Potential on Marginal Lands in APEC Economies

\begin{tabular}{|c|c|c|c|c|c|}
\hline Economy & $\begin{array}{c}\text { Marginal } \\
\text { Lands } \\
\left(\mathrm{km}^{2}\right)\end{array}$ & $\begin{array}{c}\text { Biofuels } \\
\text { Potential } \\
\left(\mathrm{hm}^{3}\right)\end{array}$ & $\begin{array}{l}\text { Biofuels } \\
\text { Density } \\
\left(\mathrm{m}^{3} / \mathrm{ha}\right)\end{array}$ & $\begin{array}{l}\text { Biomass } \\
\text { Yield } \\
\text { (t/ha) }\end{array}$ & $\begin{array}{c}\text { Suitability } \\
\text { Class }\end{array}$ \\
\hline Australia & $1,036,239$ & 153.1 & 1.5 & 3.8 & $\mathrm{~ms}$ \\
\hline Brunei & 85 & 0.004 & 0.5 & 1.3 & NS \\
\hline Canada & 376,092 & 38.7 & 1.0 & 2.6 & $\mathrm{~ms}$ \\
\hline Chile & 95,645 & 15.4 & 1.6 & 4.1 & $\mathrm{~ms}$ \\
\hline China & 511,905 & 48.2 & 0.9 & 2.4 & NS \\
\hline Indonesia & 37,123 & 6.1 & 1.6 & 4.2 & $\mathrm{~ms}$ \\
\hline Japan & 4,878 & 0.8 & 1.5 & 4.0 & $\mathrm{~ms}$ \\
\hline Korea & 1,651 & 0.2 & 1.4 & 3.6 & $\mathrm{~ms}$ \\
\hline Malaysia & 3,534 & 0.4 & 1.2 & 3.0 & $\mathrm{~ms}$ \\
\hline Mexico & 255,862 & 27.1 & 1.1 & 2.7 & $\mathrm{~ms}$ \\
\hline New Zealand & 17,299 & 3.8 & 2.2 & 5.6 & $\mathrm{~ms}-\mathrm{MS}$ \\
\hline PNG & 7,123 & 0.6 & 0.8 & 2.0 & NS \\
\hline Peru & 57,029 & 26.0 & 4.6 & 11.7 & $\mathrm{~S}$ \\
\hline Philippines & 6,357 & 0.7 & 1.1 & 2.8 & $\mathrm{~ms}$ \\
\hline Russia & 369,176 & 60.7 & 1.6 & 4.2 & $\mathrm{~ms}$ \\
\hline Chinese Taipei & 693 & 0.2 & 3.2 & 8.1 & MS \\
\hline Thailand & 17,253 & 4.1 & 2.4 & 6.1 & $\mathrm{~ms}-\mathrm{MS}$ \\
\hline United States & $1,214,007$ & 148.3 & 1.2 & 3.1 & $\mathrm{~ms}$ \\
\hline Viet Nam & 21,090 & 4.4 & 2.1 & 5.4 & $\mathrm{~ms}$ \\
\hline Total & $4,033,039$ & 538.8 & 1.3 & 3.4 & $\mathrm{~ms}$ \\
\hline
\end{tabular}

Note: Biofuels refer to ethanol fuel; columns two and three are derived from Table 4 to obtain biofuels density; * $0.39 \mathrm{~m}^{3}$ per tonne biomass; NS - not suitable; $\mathrm{ms}$ - marginally suitable; MS - moderately suitable; $\mathrm{S}$ - suitable.

Of the nineteen economies analyzed here, only four (New Zealand; Peru; Chinese Taipei; and Thailand) have Suitable or Moderately Suitable yields on average. These economies generally have better soils, warm tropical climate, and adequate rainfall on their marginal lands. Twelve economies are on average marginally suitable and three are unsuitable for biofuels feedstock production, though this overview could conceal some portions of these economies with a higher potential. 
The preponderance of the large area economies (six economies with more than $250,000 \mathrm{~km}^{2}$ of marginal lands) in the lowest classes of suitability demonstrates that while they account for $80 \%$ of the estimated total ethanol potential on such lands, the economic costs will be high. Note also that this study did not attempt to estimate the existing above ground biomass or the carbon currently in the soil. As a result, it is not certain that such low productivity lands would necessarily pay back their carbon debt if converted to biomass for biofuel production. This situation was evaluated using the GorCam model for forest lands and clearly demonstrated that there is a productivity threshold to having a positive carbon balance over a reasonable number of years (Schlamadinger and Marland 1996).

Our conclusions are somewhat similar to those of Campbell J.E., et al. (2008), who found that the highest classifications are with tropical abandoned grass lands ranging from Moderately Suitable to Very Suitable. But these are hot spots and the global weighted area average of all of the abandoned agricultural lands was found to be marginally suitable for above ground biomass. 


\section{Conclusions}

Marginal lands present severe constraints to plant mass production. Non-optimum conditions of $\mathrm{pH}$, poor soils, inadequate or excessive water availability, and steep terrain all present major challenges to sustainable biomass production without major investments.

Amelioration of these lands is possible through investment in irrigation and conservation schemes, but is often very expensive. Examples abound of irrigation projects in areas of dryness such as the Red Flag (Hongi) canal in the Taihang Mountains of China or the extensive schemes of the Murray-Darling Basin of Australia. Similarly, the management of both slope and water in the ancient rice terraces of the Ifuago in the cordillera of northern Luzon in the Philippines is an example of overcoming limitations in a sustainable way. Many of the other APEC economies have examples of such amelioration.

The goal of this study was to examine the marginal lands in APEC economies and evaluate their biomass productivity potential. The marginal lands were identified using the GAEZ system of the FAO. The study's biomass production assessment methodology was to take the defined areas and to look at their status today. It used a combination of assessment of the current vegetation cover and a calculation of the net primary productivity. This is an assessment of the potential of a given land parcel on an "as-is" basis, without any attempt to estimate the potential under conditions that would prevail if improvements such as irrigation were undertaken. A note of caution is that it is based on a snapshot of a particular year: the northern hemisphere growing season of 2000 and the southern hemisphere season of $2000-2001$. This growth year window was a La Nina period of the El Nino Southern Oscillation (ENSO) in the Pacific region, a period of relatively high rainfall in Australia prior to the extended drought that started in 2002-3 and has continued to the present. On the other hand, the assumptions about the rate at which plants convert sunlight to biomass are quite conservative in view of agricultural advancements.

Many of the marginal lands in APEC economies are in regions that are relatively dry, as illustrated at a glance in Figure 2. These include regions with rain deficit adjacent to the major mountain chains of North and South America, Asia and Australia. Data for the tropical regions such as the Asian Islands are unlikely to be as affected as much by the time window chosen, though even so the ENSO still has some effects. 
The net primary productivity, in tonnes of carbon, was derived from extensive data sets and translated into annual yield of lignocellulosic biomass, typical of grasses such as switchgrass and other thin-stemmed perennials, or thick-stemmed grasses in tropical areas. Other lignocellulosics that would be similar are short-rotation tree species with willow and poplar as examples in temperate regions and eucalyptus in more tropical environments. These crop types meet the criteria of non-edible crops and will give the highest biomass potential.

The biomass yield was translated into suitability bands, calculated for each economy on average and not for each $100 \mathrm{~km}^{2}$ cell separately. Very Suitable (VS) and Suitable (S) lands with yields greater than $10 \mathrm{t} / \mathrm{ha} / \mathrm{yr}$ can be considered economically viable as the areas needed are compact and the harvesting effort is minimized. Moderately suitable (MS) lands of 7-10 t/ha/yr may also have significant economic potential. As biomass productivity declines, the areas for a given output increase; harvesting effort not only increases, but the efficiency goes down, more equipment is needed and the logistics of biomass delivery to the biofuel processing plants become more challenging. The marginal suitable (ms) category is a yield of $3-5 \mathrm{t} / \mathrm{ha} / \mathrm{yr}$ and the unsuitable areas (NS) have a productivity of less than $2 \mathrm{t} / \mathrm{ha} / \mathrm{yr}$. The ms and NS categories do not preclude the development and use of biomass for local markets, but would not offer an economic proposition in terms of large scale biofuel production for domestic or export markets.

Among the APEC economies, only Thailand's marginal lands achieved an average score of Suitable, while the marginal lands of three economies (Brunei; China; and Papua New Guinea) were rated as unsuitable for biofuels feedstock production. The marginal lands in the remaining economies were in the range of marginally to moderately suitable, and represent $90 \%$ of the initial land area assessed. Again, it should be noted that this analysis is done for each economy on average, ignoring potential hot spots.

The total annual biomass resource potential on marginal lands in APEC economies appears to be around $1.3 \mathrm{Gt}$, which translates roughly into about $540 \mathrm{hm}^{3}$ of ethanol fuel (260 Mt of gasoline equivalent). Current gasoline consumption in the APEC region is about $621 \mathrm{Mt}$ and crude oil import is approximately $1.3 \mathrm{Gt}$ (IEA 2006). Therefore the ethanol volume from marginal lands would displace two-fifths of the region's gasoline consumption and one-fifth of its crude oil import. 
Many economies could replace a substantial volume of their current gasoline consumption and crude oil import with ethanol from marginal lands, as illustrated in the Appendix. These include Peru; Australia; Chile; Viet Nam; and New Zealand. But there could be technical or economic restrictions on the use of these lands, which suggests that only a portion of this potential can be realized. This portion would be different in each economy and could be determined by a detailed techno-economic feasibility assessment, which is beyond the scope of this study.

Previous work by the authors (Milbrandt, A., Overend, R. 2008) evaluated the ethanol potential from existing lignocellulosic biomass (primarily crop and forest residues) in the APEC region. The study estimated similar volume of ethanol potential, $509 \mathrm{hm}^{3}$ of ethanol fuel or $245 \mathrm{Mt}$ of gasoline equivalent, enough to displace two-fifths of the region's gasoline consumption and onefifth of its crude oil import. Comparing the results from both studies at an economy level, it appears that in some economies (such as China; Indonesia; Japan; Korea; Malaysia; the Philippines; Thailand; and Viet Nam) it might be best to utilize the existing lignocellulosic biomass rather than to develop their marginal lands. The ethanol potential from these resources is much higher than that from marginal lands (Table 7 and Table 8 in the Appendix). On the other hand, economies such as Australia; Canada; Chile; Mexico; New Zealand; Russia; and the United States should consider developing their marginal lands given their high biomass, and ethanol production potential. However, large lignocellulosic biomass resources exist in those economies as well. Therefore, a combination of feedstock - lignocellulosic biomass from farm and forest residues and purposely grown on marginal lands - would assure a sustainable biomass resource supply for biofuels production in these economies. Such production could substantially displace current petroleum products' import and consumption.

The present study evaluates only the ethanol potential on marginal lands. Biodiesel could present very good opportunities for some of these lands in tropical regions, so future work should evaluate the biodiesel potential on marginal lands in APEC economies and compare it with the results from the previous study. More detailed assessments at a sub-regional or an economy level, with particular attention to multi-year series of NPP data and a finer than 100 $\mathrm{km}^{2}$ spatial resolution, would also provide a better understanding of the biofuels potential on marginal lands in the APEC region. Since interest in biofuels is in large part driven by greenhouse gas mitigation policies, future resource assessment work could be linked to climate modeling efforts, which are now starting to have the ability to predict regional changes in climate that would affect biofuel output. 


\section{References}

1. Biomass Research and Development Board, Increasing Feedstock Production for Biofuels Economic Drivers, Environmental Implications, and the Role of Research. BR\&Di, Washington DC.148pp, 2008

2. Campbell, J. E., D. B. Lobell, et al. (2008). "The Global Potential of Bioenergy on Abandoned Agriculture Lands." Environmental Science \& Technology 42(15): 5791-5794.

3. ESRI, Licensed data, http://www.esri.com/data/data-maps/index.html

4. Eswaran, H., F. Beinroth, and P. Reich. 1999. Global land resources and population supporting capacity. Am. J. Alternative Agric. 14:129-136.

5. FAO, GeoNetwork, Accessed January 2008, http://www.fao.org/geonetwork/srv/en/main.home

6. FAO-IIASA, Global Agro-Ecological Zones, Accessed January 2008, http://www.iiasa.ac.at/Research/LUC/GAEZ/index.htm

7. Goudriaan, J. and H. H. van Laar, Modeling potential crop growth processes, Kluwer Academic Publishers, Dordrecht, The Netherlands, 1994. pp. 238.

8. International Energy Agency (IEA), Country energy statistics, Oil by Country, 2006. http://www.iea.org/Textbase/stats/prodresult.asp?PRODUCT=Oil

9. IIASA, European Biomass Resources for Transportation Fuels, Policy Workshop Brussels, March 14 2008, http://www.iiasa.ac.at/Research/LUC/luc07/Homepage-NewsHighlights/Brussels Workshop March08.pdf

10. Milbrandt, A., Overend, R., Survey of Biomass Resource Assessments and Assessment Capabilities in APEC Economies, November 2008, http://www.biofuels.apec.org/pdfs/ewg 2008 biomass resource assessment.pdf

11. Penn State University, Digital Chart of the World, Accessed January 2009, http://www.maproom.psu.edu/dcw/

12. Schlamadinger, B. and G. Marland (1996). "The role of forest and bioenergy strategies in the global carbon cycle." Biomass and Bioenergy 10(5-6): 275-300.

13. Sinclair, T.R., Muchow, R.C., 1999. Radiation use efficiency. Adv. Agron. 65, 215- 65

14. UNEP-IUCN, World Database on Protected Areas (WDPA) - Released February 2009, Accessed February 2009, http://www.wdpa.org/

15. USDA, World Soil Resources, Accessed January 2009, http://soils.usda.gov/use/worldsoils/mapindex/index.html

16. Veroustraete F., Sabbe H., European Net Ecosystem Productivity Determined with Space-borne Sensors, Manuscript for Topics in Ecology: Lessons from the past towards the future. Revised February 2000, http://geofront.vgt.vito.be/geosuccess/documents/European\%20NEP.pdf

17. VITO (Flemish Institute for Technological Research), GeoSuccess, Accessed March 2009, http://geofront.vgt.vito.be/geosuccess/relay.do?dispatch=introduction 
APPENDIX 
Table 6 Ethanol Potential from Marginal Lands, Share of Current Gasoline Consumption and Crude Oil Import in APEC Economies

\begin{tabular}{|c|c|c|c|c|c|c|c|}
\hline Economy & $\begin{array}{c}\text { Biomass Resource } \\
\text { Potential } \\
\text { ('000 tonnes) }\end{array}$ & $\begin{array}{l}\text { Ethanol Potential } \\
\text { (hm3) }\end{array}$ & $\begin{array}{c}\text { Gasoline } \\
\text { Equivalent } \\
\text { ('000 tonnes) }\end{array}$ & $\begin{array}{c}\text { Gasoline } \\
\text { Consumption } \\
\text { ('000 tonnes)* }\end{array}$ & $\begin{array}{c}\text { Share of } \\
\text { Gasoline } \\
\text { Consumption } \\
(\%)\end{array}$ & $\begin{array}{c}\text { Crude Oil Import } \\
(\text { '000 tonnes)* }\end{array}$ & $\begin{array}{c}\text { Share of Crude } \\
\text { Oil Import } \\
(\%)\end{array}$ \\
\hline Australia & 389,564 & 153.1 & 73,754 & 13,743 & 536.7 & 18,837 & 391.5 \\
\hline Brunei & 11 & 0.004 & 1.9 & 202 & 1.0 & & \\
\hline Canada & 98,521 & 38.7 & 18,643 & 30,085 & 62.0 & 41,468 & 45.0 \\
\hline Chile & 39,120 & 15.4 & 7,419 & 2,079 & 356.8 & 10,664 & 69.6 \\
\hline China & 122,719 & 48.2 & 23,220 & 49,870 & 46.6 & 145,175 & 16.0 \\
\hline Indonesia & 15,494 & 6.1 & 2,939 & 13,055 & 22.5 & 15,344 & 19.2 \\
\hline Japan & 1,924 & 0.8 & 385 & 44,083 & 0.9 & 197,500 & 0.2 \\
\hline Korea & 588 & 0.2 & 96 & 7,013 & 1.4 & 119,440 & 0.1 \\
\hline Malaysia & 1,052 & 0.4 & 193 & 7,888 & 2.4 & 7,861 & 2.5 \\
\hline Mexico & 69,000 & 27.1 & 13,055 & 29,712 & 43.9 & & \\
\hline New Zealand & 9,599 & 3.8 & 1,831 & 2,347 & 78.0 & 4,591 & 39.9 \\
\hline PNG & 1,432 & 0.6 & 289 & $\mathrm{~N} / \mathrm{A}$ & $\mathrm{N} / \mathrm{A}$ & 435 & 66.4 \\
\hline Peru & 66,225 & 26 & 12,525 & 752 & $1,665.6$ & 5,078 & 246.7 \\
\hline The Philippines & 1,793 & 0.7 & 337 & 2,619 & 12.9 & 10,735 & 3.1 \\
\hline Russia & 154,412 & 60.7 & 29,241 & 27,893 & 104.8 & & \\
\hline Chinese Taipei & 558 & 0.2 & 96 & 7,649 & 1.3 & 51,682 & 0.2 \\
\hline Thailand & 10,394 & 4.1 & 1,975 & 5,263 & 37.5 & 39,892 & 5.0 \\
\hline United States & 377,413 & 148.3 & 71,441 & 372,851 & 19.2 & 537,755 & 13.3 \\
\hline Viet Nam & 11,281 & 4.4 & 2,120 & 2,690 & 78.8 & & \\
\hline APEC Total & $1,371,098$ & 538.8 & 259,561 & 619,794 & 41.9 & $1,206,457$ & 21.5 \\
\hline
\end{tabular}

* Source: IEA 2006; gray areas - not applicable; N/A - information not available 
Table 7 Ethanol Potential from Existing Biomass Resources, Share of Current Gasoline Consumption and Crude Oil Import in APEC Economies

\begin{tabular}{|c|c|c|c|c|c|c|c|c|}
\hline Economy & Feedstock Type & $\begin{array}{c}\text { Resource } \\
\text { Availability } \\
\text { ('000 tonnes) }\end{array}$ & $\begin{array}{l}\text { Ethanol } \\
\text { Potential } \\
\text { (hm3) }\end{array}$ & $\begin{array}{c}\text { Gasoline } \\
\text { Equivalent } \\
\text { ('000 tonnes) }\end{array}$ & $\begin{array}{c}\text { Gasoline } \\
\text { Consumption } \\
\text { ('000 tonnes)* }\end{array}$ & $\begin{array}{c}\text { Share of } \\
\text { Gasoline } \\
\text { Consumption } \\
(\%)\end{array}$ & $\begin{array}{l}\text { Crude Oil Import } \\
\text { ('000 tonnes)* }\end{array}$ & $\begin{array}{c}\text { Share of } \\
\text { Crude Oil } \\
\text { Import } \\
(\%)\end{array}$ \\
\hline Australia & $\begin{array}{l}\text { crop, forest, and primary } \\
\text { mill residues; urban wood } \\
\text { waste }\end{array}$ & 36,700 & 11.0 & 5,299 & 14,520 & 36.5 & 20,070 & 26.4 \\
\hline Brunei & & & & & 196 & & & \\
\hline Canada & $\begin{array}{l}\text { crop, forest, and primary } \\
\text { mill residues; hog fuel piles }\end{array}$ & 71,000 & 21.3 & 10,261 & 29,751 & 34.5 & 45,336 & 22.6 \\
\hline Chile & primary mill residues & 3,254 & 0.9 & 434 & 2,081 & 20.8 & 10,219 & 4.2 \\
\hline China & $\begin{array}{l}\text { crop, forest, and primary } \\
\text { mill residues }\end{array}$ & 788,000 & 236.0 & 113,689 & 46,097 & 246.6 & 126,817 & 89.6 \\
\hline Hong Kong & & & & & 325 & & 352 & \\
\hline Indonesia & $\begin{array}{l}\text { crop residues; sugar cane } \\
\text { bagasse; oil-palm, rubber, } \\
\text { and coconut residues }\end{array}$ & 74,000 & 22.2 & 10,695 & 12,942 & 82.6 & 20,829 & 51.3 \\
\hline Japan & $\begin{array}{l}\text { crop and forest residues; } \\
\text { urban wood waste }\end{array}$ & 15,000 & 4.5 & 2,168 & 44,391 & 4.9 & 207,266 & 1.0 \\
\hline Korea & crop and forest residues & 13,100 & 3.9 & 1,879 & 6,969 & 27.0 & 113,234 & 1.7 \\
\hline Malaysia & \begin{tabular}{|l|} 
crop residues; sugar cane \\
bagasse; oil-palm and wood- \\
processing residues
\end{tabular} & 32,392 & 9.7 & 4,673 & 7,756 & 60.2 & 7,885 & 59.3 \\
\hline Mexico & $\begin{array}{l}\text { crop, logging, and primary } \\
\text { mill residues }\end{array}$ & 74,500 & 22.4 & 10,767 & 27,704 & 38.9 & & \\
\hline New Zealand & $\begin{array}{l}\text { crop, logging, and primary } \\
\text { mill residues; horticultural } \\
\text { and urban wood waste }\end{array}$ & 5,500 & 1.7 & 795 & 2,325 & 34.2 & 4,488 & 17.7 \\
\hline PNG & $\begin{array}{l}\text { logging, oil-palm, and } \\
\text { coconut residues; sugar } \\
\text { cane bagasse } \\
\end{array}$ & $\mathrm{N} / \mathrm{A}$ & $\mathrm{N} / \mathrm{A}$ & $\mathrm{N} / \mathrm{A}$ & $\mathrm{N} / \mathrm{A}$ & $\mathrm{N} / \mathrm{A}$ & 435 & $\mathrm{~N} / \mathrm{A}$ \\
\hline Peru & $\begin{array}{l}\text { crop, logging, and oil-palm } \\
\text { residues; sugar cane } \\
\text { bagasse }\end{array}$ & $\mathrm{N} / \mathrm{A}$ & $\mathrm{N} / \mathrm{A}$ & $\mathrm{N} / \mathrm{A}$ & 771 & $\mathrm{~N} / \mathrm{A}$ & 4,809 & $\mathrm{~N} / \mathrm{A}$ \\
\hline The Philippines & $\begin{array}{l}\text { crop, logging, and coconut } \\
\text { residues; sugar cane } \\
\text { bagasse }\end{array}$ & 18,000 & 5.4 & 2,601 & 4,111 & 63.3 & 10,681 & 24.4 \\
\hline Russia & crop and forest residues & 100,000 & 30.0 & 14,452 & 26,260 & 55.0 & & \\
\hline Singapore & & & & & 727 & & 54,786 & \\
\hline Chinese Taipei & crop residues & 1,900 & 0.6 & 275 & 7,845 & 3.5 & 54,035 & 0.5 \\
\hline Thailand & $\begin{array}{l}\text { crop residues; sugar cane } \\
\text { bagasse; oil-palm and } \\
\text { coconut residues }\end{array}$ & 47,800 & 14.3 & 6,889 & 5,280 & 130.5 & 39,815 & 17.3 \\
\hline United States & $\begin{array}{l}\text { crop, forest, primary mill, } \\
\text { and secondary mill residues; } \\
\text { urban wood waste }\end{array}$ & 324,448 & 97.3 & 46,873 & 373,930 & 12.5 & 538,651 & 8.7 \\
\hline Viet Nam & $\begin{array}{l}\text { crop, wood-processing, and } \\
\text { coconut residues; sugar } \\
\text { cane bagasse }\end{array}$ & 93,000 & 27.9 & 13,440 & 2,546 & 527.9 & & \\
\hline APEC Total & & $1,698,594$ & 509.0 & 245,189 & 616,527 & 39.8 & $1,259,708$ & 19.5 \\
\hline
\end{tabular}

Source: Milbrandt, A., Overend, R. 2008; * IEA, 2005; gray areas - not applicable; N/A - information not available 


\section{Australia}

Total land area $-7,694,273 \mathrm{~km}^{2}$

Population - 20,434,176

Marginal lands $-1,036,239 \mathrm{~km}^{2}(13.5 \%$ of total area)

Biomass resource potential on marginal lands $-389,564,000$ tonnes/year

Ethanol potential from marginal lands $-153 \mathrm{hm}^{3}$ (537\% of current gasoline consumption)

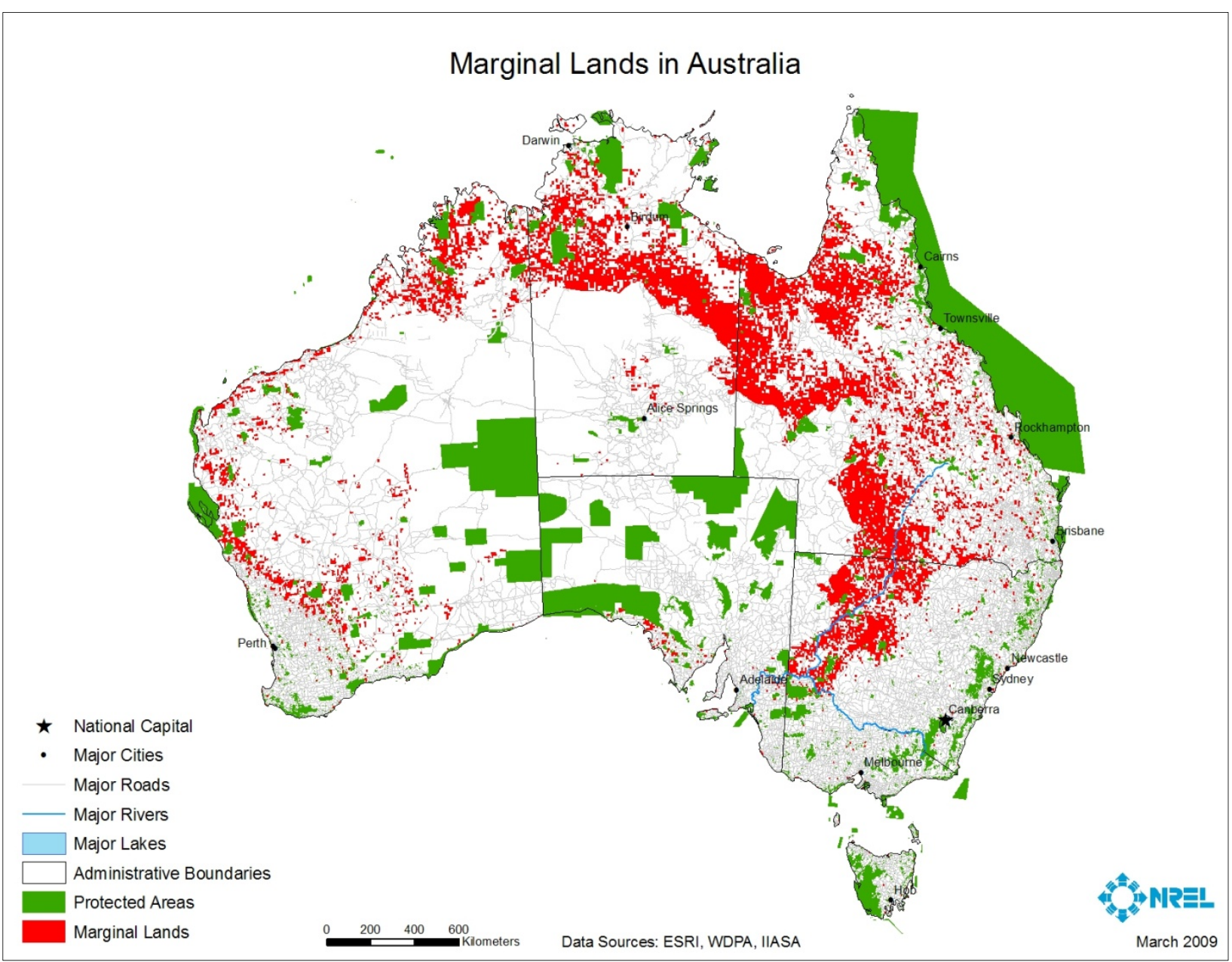

Figure 5 Marginal Lands in Australia 
Total land area $-6,078 \mathrm{~km}^{2}$

Population - 386,511

Marginal lands $-85 \mathrm{~km}^{2}(1.4 \%$ of total area $)$

Biomass resource potential on marginal lands $-10,723$ tonnes/year

Ethanol potential from marginal lands $-0.004 \mathrm{hm}^{3}$ (1\% of current gasoline consumption)

Marginal Lands in Brunei Darussalam

$\star \quad$ National Capital

- Major Cities Major Roads

Major Rivers

Major Lakes

Administrative Boundaries

Protected Areas

Marginal Lands

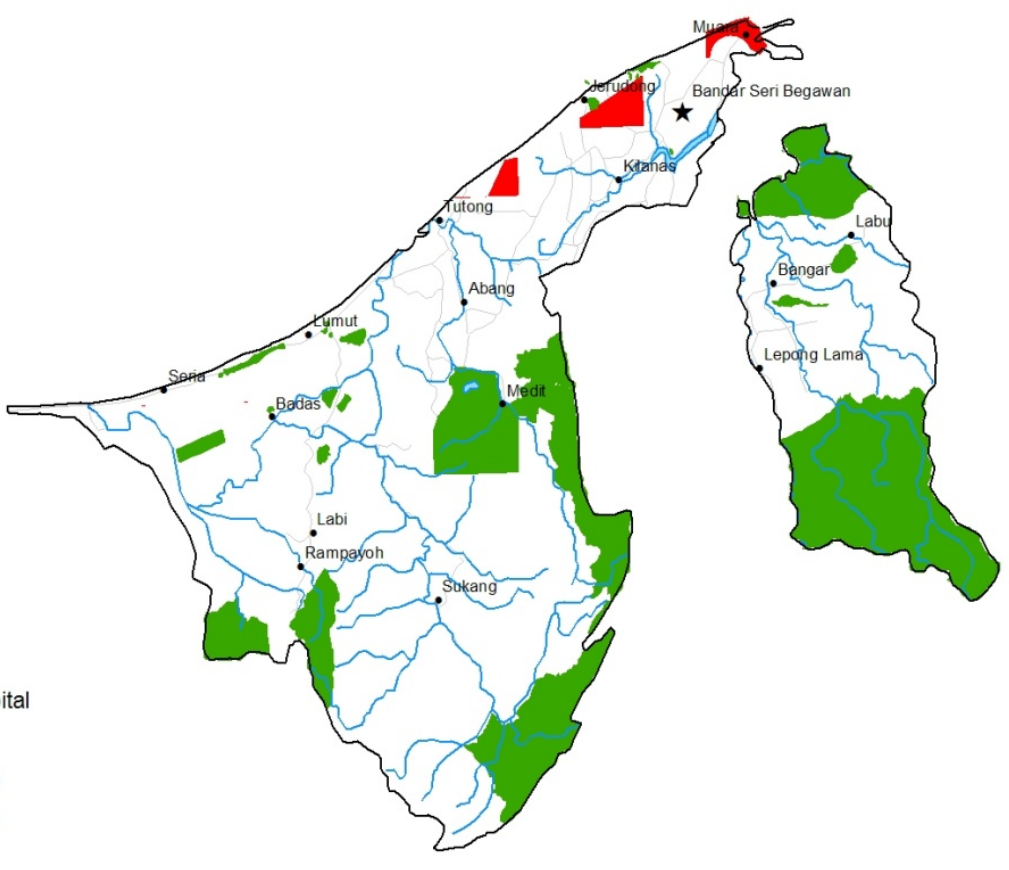

$\begin{array}{lll}0 \quad 10 \quad 20 \quad 30 & 30 \\ \text { Kilometers }\end{array}$

Data Sources: ESRI, WDPA, IIASA

Figure 6 Marginal Lands in Brunei Darussalam 


\section{Canada}

Total land area $-9,832,884 \mathrm{~km}^{2}$

Population - 33,390,141

Marginal lands $-376,092 \mathrm{~km}^{2}$ (3.8\% of total area)

Biomass resource potential on marginal lands $-98,521,000$ tonnes/year

Ethanol potential from marginal lands $-38.7 \mathrm{hm}^{3}$ ( $62 \%$ of current gasoline consumption)

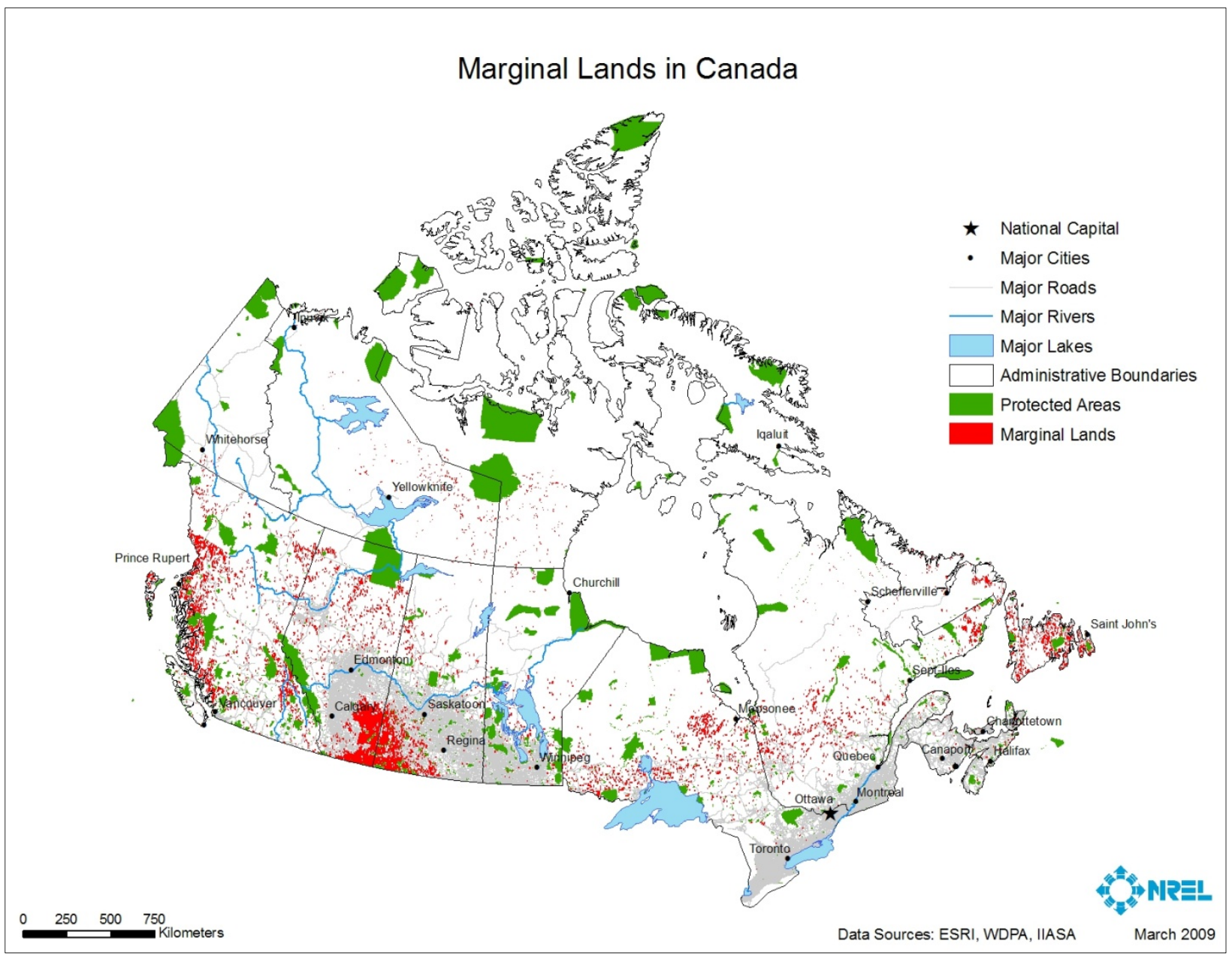

Figure 7 Marginal Lands in Canada 
Total land area $-722,511 \mathrm{~km}^{2}$

Population - 16,284,741

Marginal lands $-95,645 \mathrm{~km}^{2}$ (13\% of total area)

Biomass resource potential on marginal lands $-39,120,000$ tonnes/year

Ethanol potential from marginal lands $-15.4 \mathrm{hm}^{3}$ (357\% of current gasoline consumption)

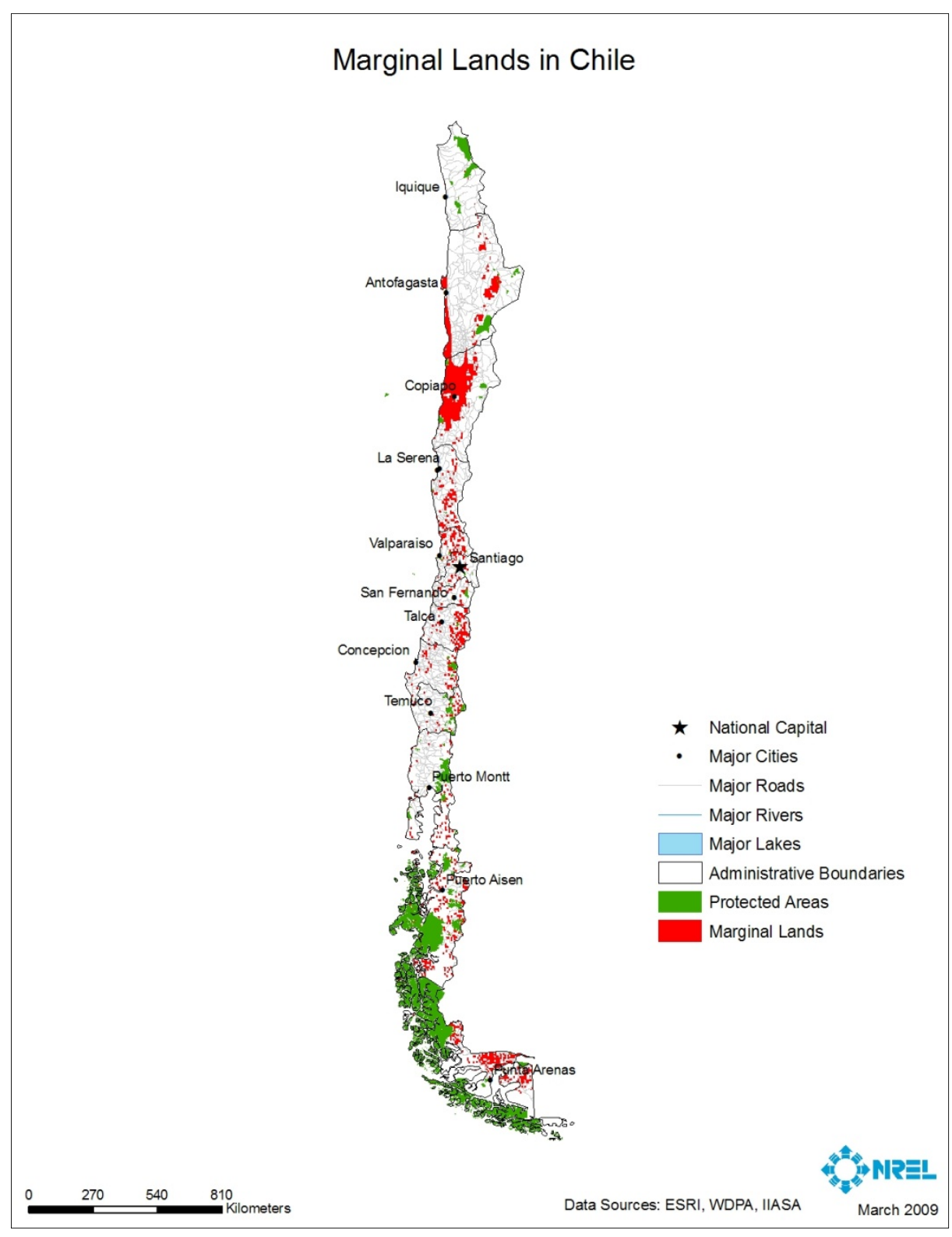

Figure 8 Marginal Lands in Chile 
Total land area $-9,402,887 \mathrm{~km}^{2}$

Population - 1,321,851,888

Marginal lands $-511,905 \mathrm{~km}^{2}$ ( $5.4 \%$ of total area)

Biomass resource potential on marginal lands $-122,719,000$ tonnes/year

Ethanol potential from marginal lands $-48 \mathrm{hm}^{3}$ ( $47 \%$ of current gasoline consumption)

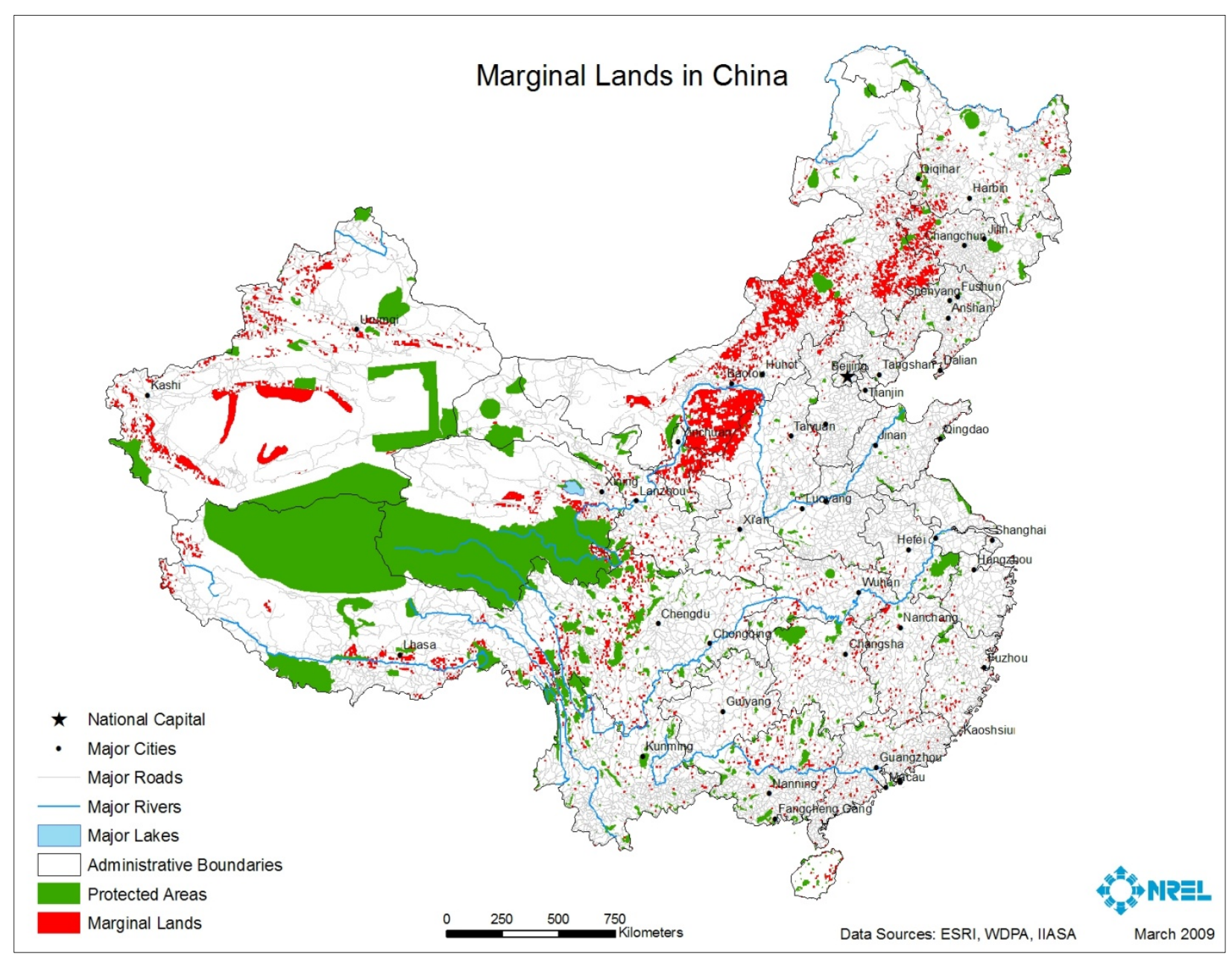

Figure 9 Marginal Lands in China 


\section{Indonesia}

Total land area - 1,847,033 $\mathrm{km}^{2}$

Population - 234,693,997

Marginal lands $-37,123 \mathrm{~km}^{2}$ ( $2 \%$ of total area)

Biomass resource potential on marginal lands $-15,494,000$ tonnes/year

Ethanol potential from marginal lands $-6 \mathrm{hm}^{3}$ (23\% of current gasoline consumption)

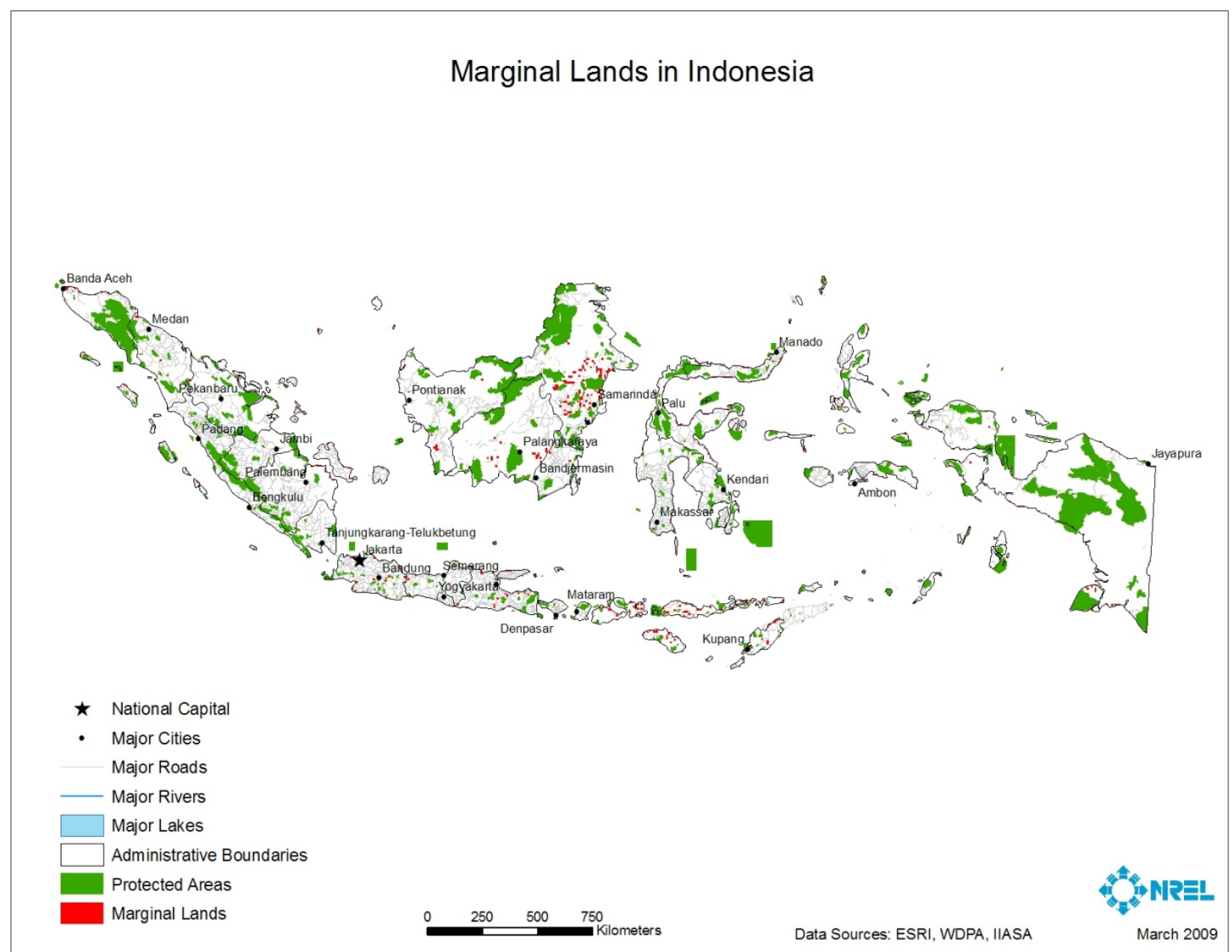

Figure 10 Marginal Lands in Indonesia 
Total land area $-370,727 \mathrm{~km}^{2}$

Population - 127,467,972

Marginal lands $-4,878 \mathrm{~km}^{2}(1.3 \%$ of total area)

Biomass resource potential on marginal lands $-1,924,000$ tonnes/year

Ethanol potential from marginal lands $-0.8 \mathrm{hm}^{3}$ (1\% of current gasoline consumption)

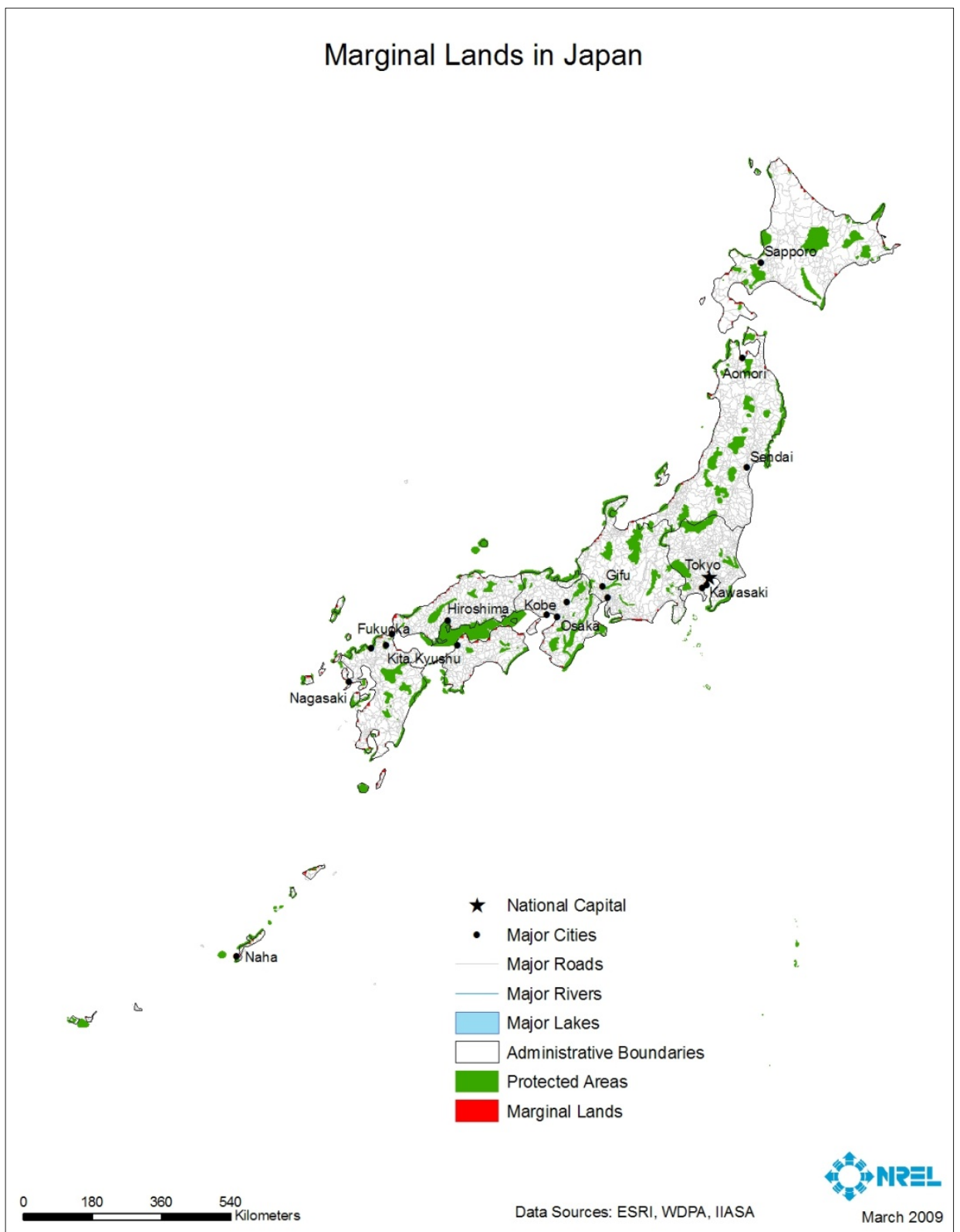

Figure 11 Marginal Lands in Japan 
Total land area $-94,773 \mathrm{~km}^{2}$

Population - 49,044,790

Marginal lands $-1,651 \mathrm{~km}^{2}(1.7 \%$ of total area)

Biomass resource potential on marginal lands $-588,000$ tonnes/year

Ethanol potential from marginal lands $-0.2 \mathrm{hm}^{3}$ ( $1.4 \%$ of current gasoline consumption)

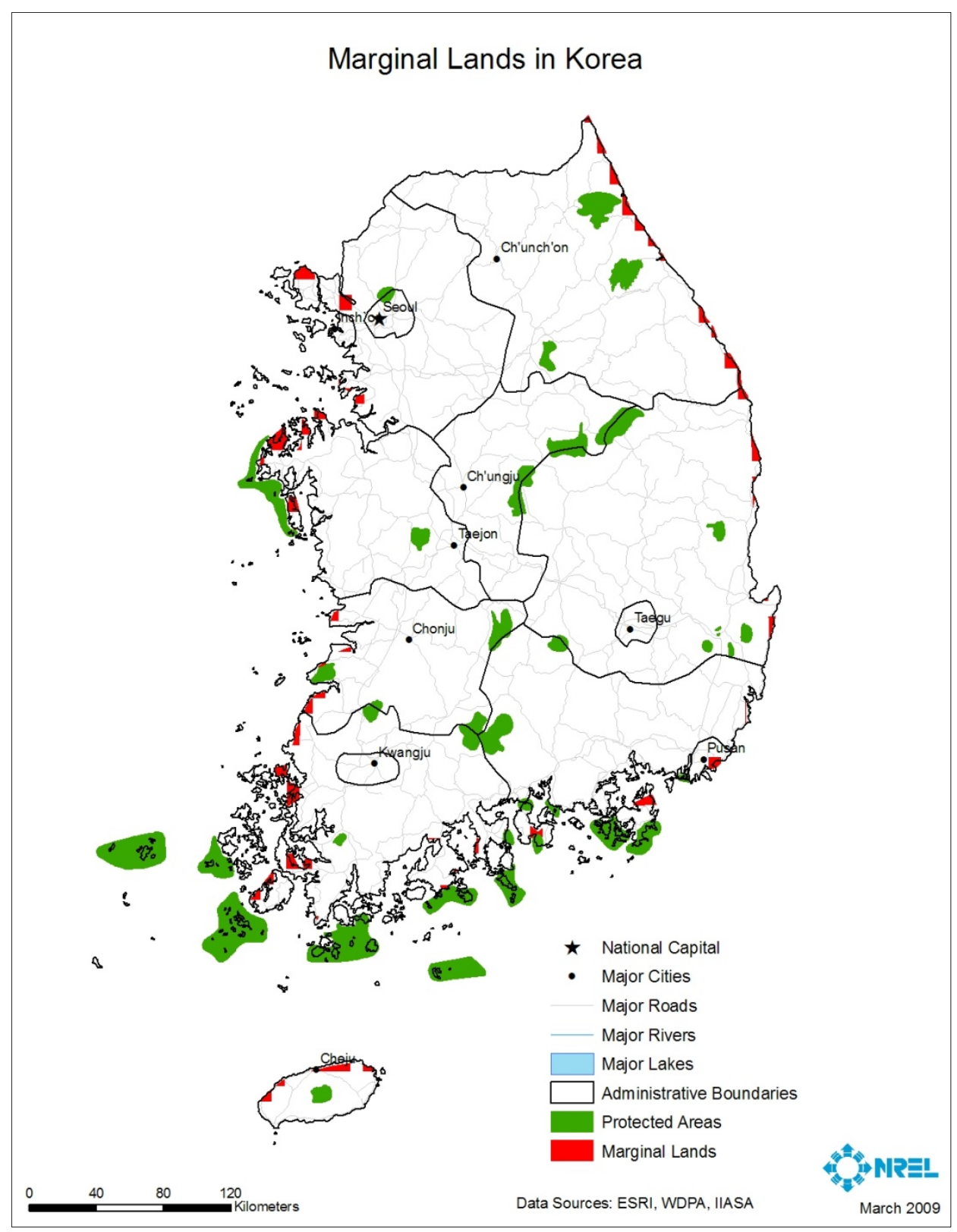

Figure 12 Marginal Lands in Republic of Korea 
Total land area $-328,536 \mathrm{~km}^{2}$

Population - 24,821,286

Marginal lands $-3,534 \mathrm{~km}^{2}$ (1\% of total area)

Biomass resource potential on marginal lands - 1,000,000 tonnes/year

Ethanol potential from marginal lands $-0.4 \mathrm{hm}^{3}$ (2.4\% of current gasoline consumption)

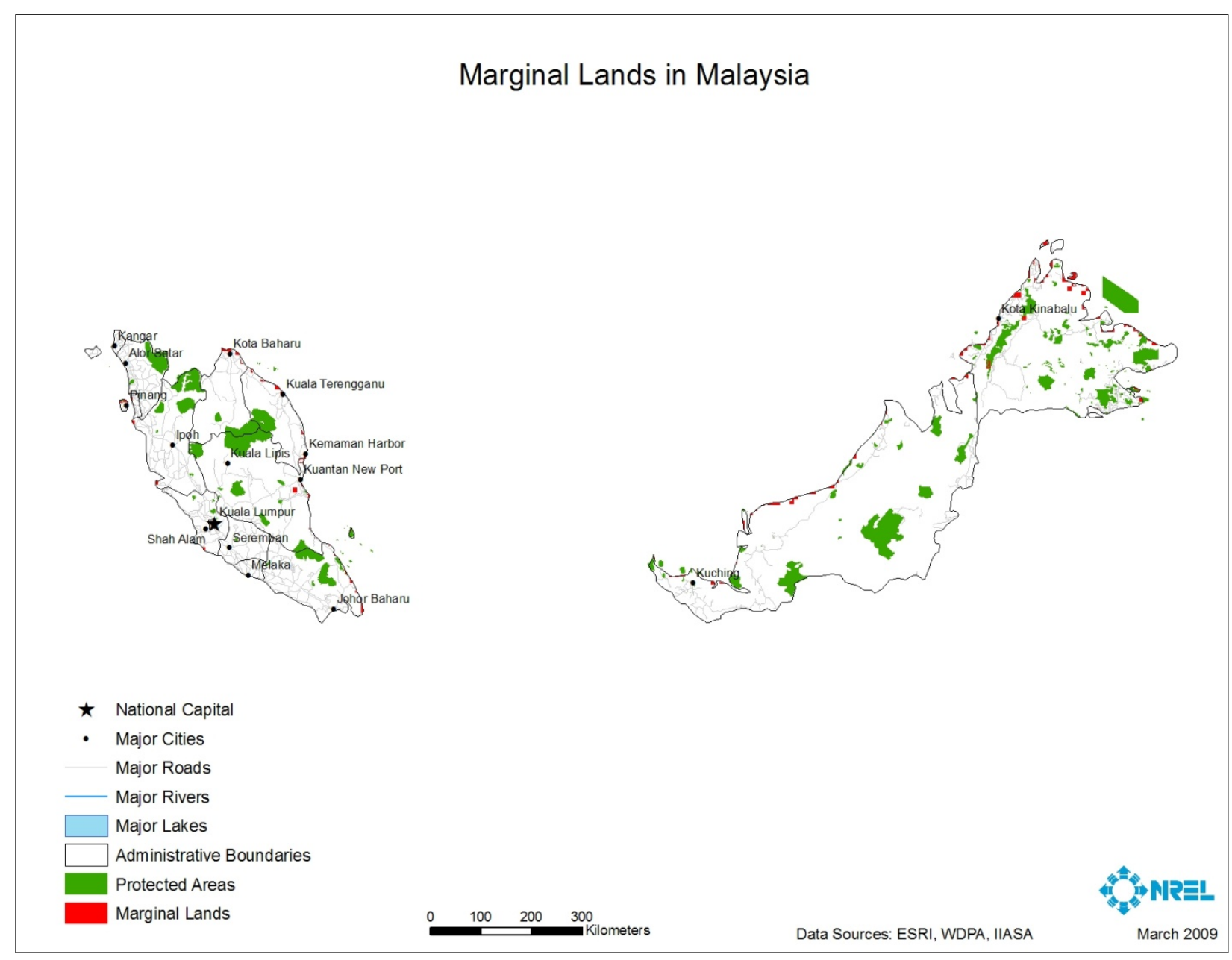

Figure 13 Marginal Lands in Malaysia 


\section{Mexico}

Total land area $-1,953,851 \mathrm{~km}^{2}$

Population - 108,700,891

Marginal lands $-255,862 \mathrm{~km}^{2}$ (13\% of total area)

Biomass resource potential on marginal lands $-69,000,000$ tonnes/year

Ethanol potential from marginal lands $-27 \mathrm{hm}^{3}$ (44\% of current gasoline consumption)

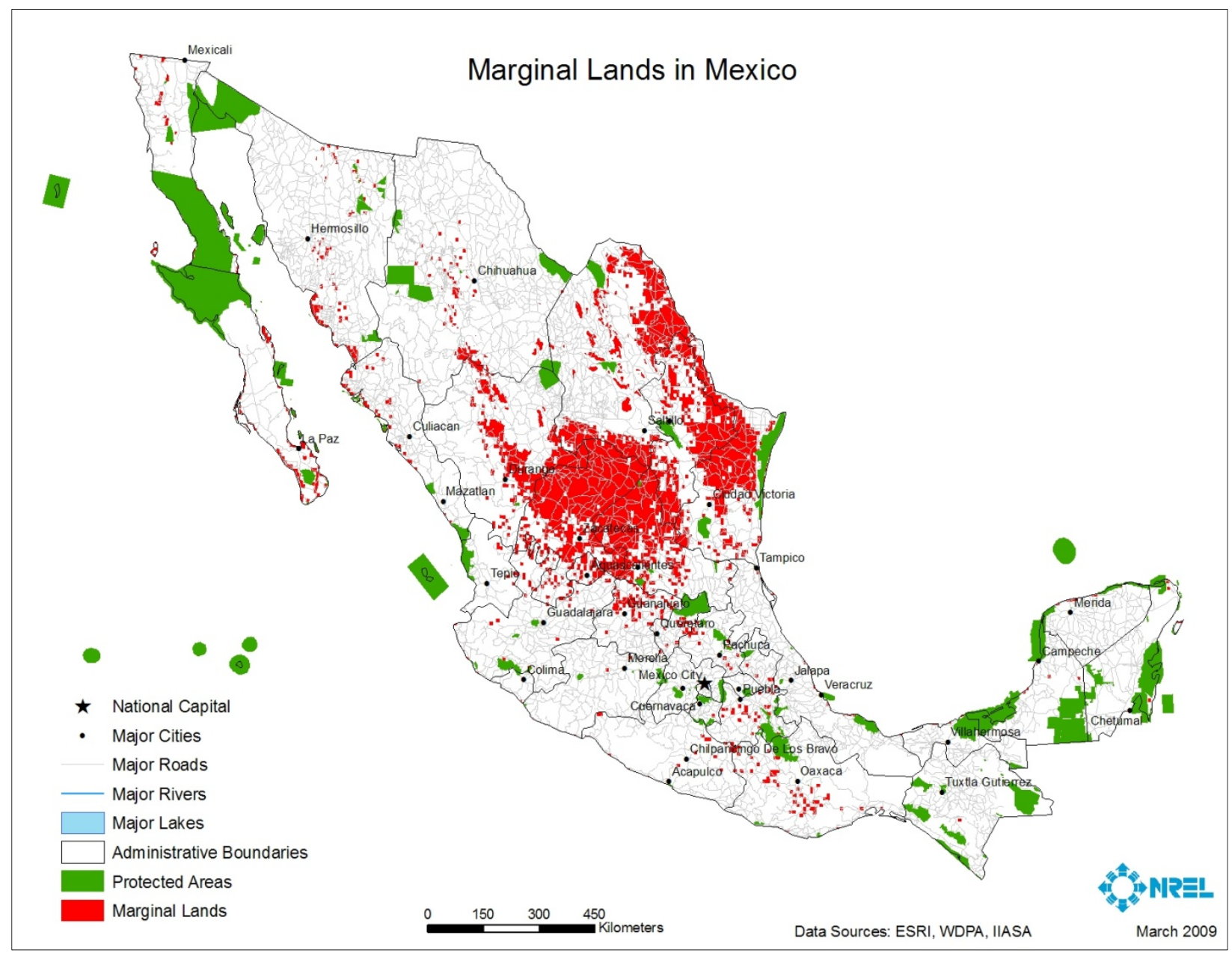

Figure 14 Marginal Lands in Mexico 
Total land area $-267,214 \mathrm{~km}^{2}$

Population - 4,115,771

Marginal lands $-17,299 \mathrm{~km}^{2}(6.5 \%$ of total area $)$

Biomass resource potential on marginal lands $-9,599,000$ tonnes/year

Ethanol potential from marginal lands $-3.8 \mathrm{hm}^{3}$ ( $78 \%$ of current gasoline consumption)

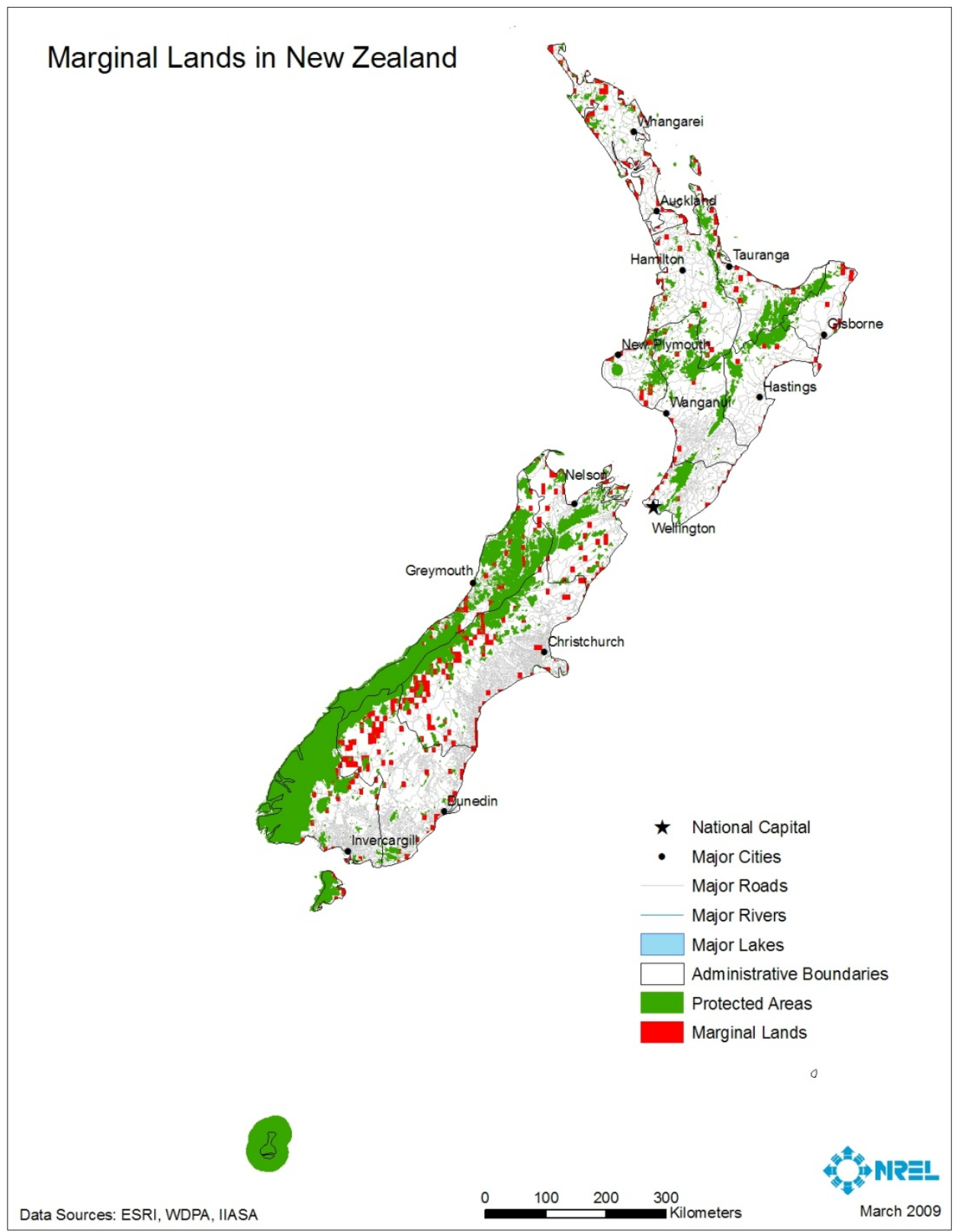

Figure 15 Marginal Lands in New Zealand 
Total land area $-458,666 \mathrm{~km}^{2}$

Population - 5,795,887

Marginal lands $-7,123 \mathrm{~km}^{2}$ ( $1.6 \%$ of total area)

Biomass resource potential on marginal lands $-1,432,000$ tonnes/year

Ethanol potential from marginal lands $-0.6 \mathrm{hm}^{3}$ (current gasoline consumption not available)

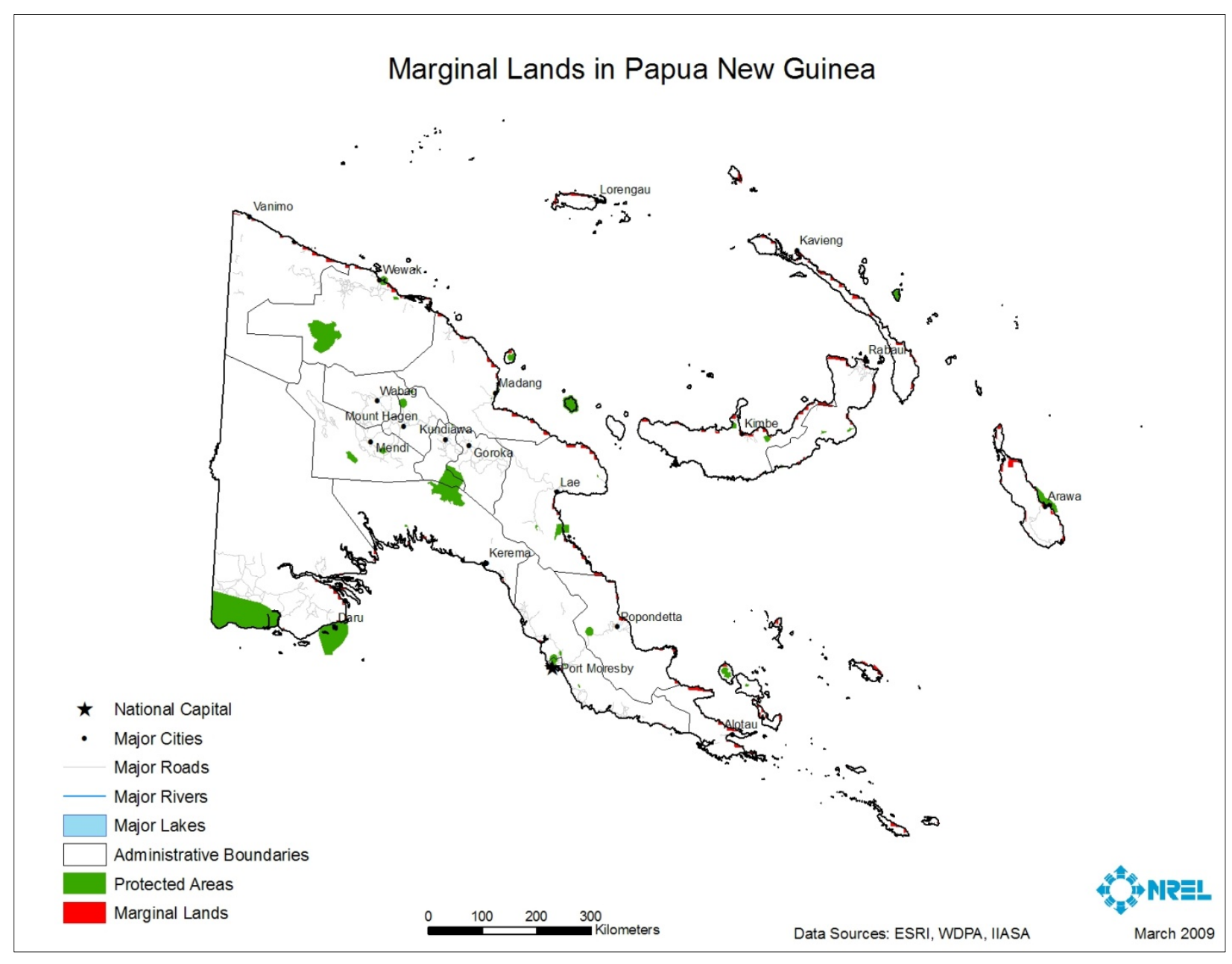

Figure 16 Marginal Lands in Papua New Guinea 
Total land area $-1,296,605 \mathrm{~km}^{2}$

Population - 28,674,757

Marginal lands $-57,029 \mathrm{~km}^{2}$ ( $4.4 \%$ of total area)

Biomass resource potential on marginal lands $-66,225,000$ tonnes/year

Ethanol potential from marginal lands $-26 \mathrm{hm}^{3}(1,666 \%$ of current gasoline consumption)

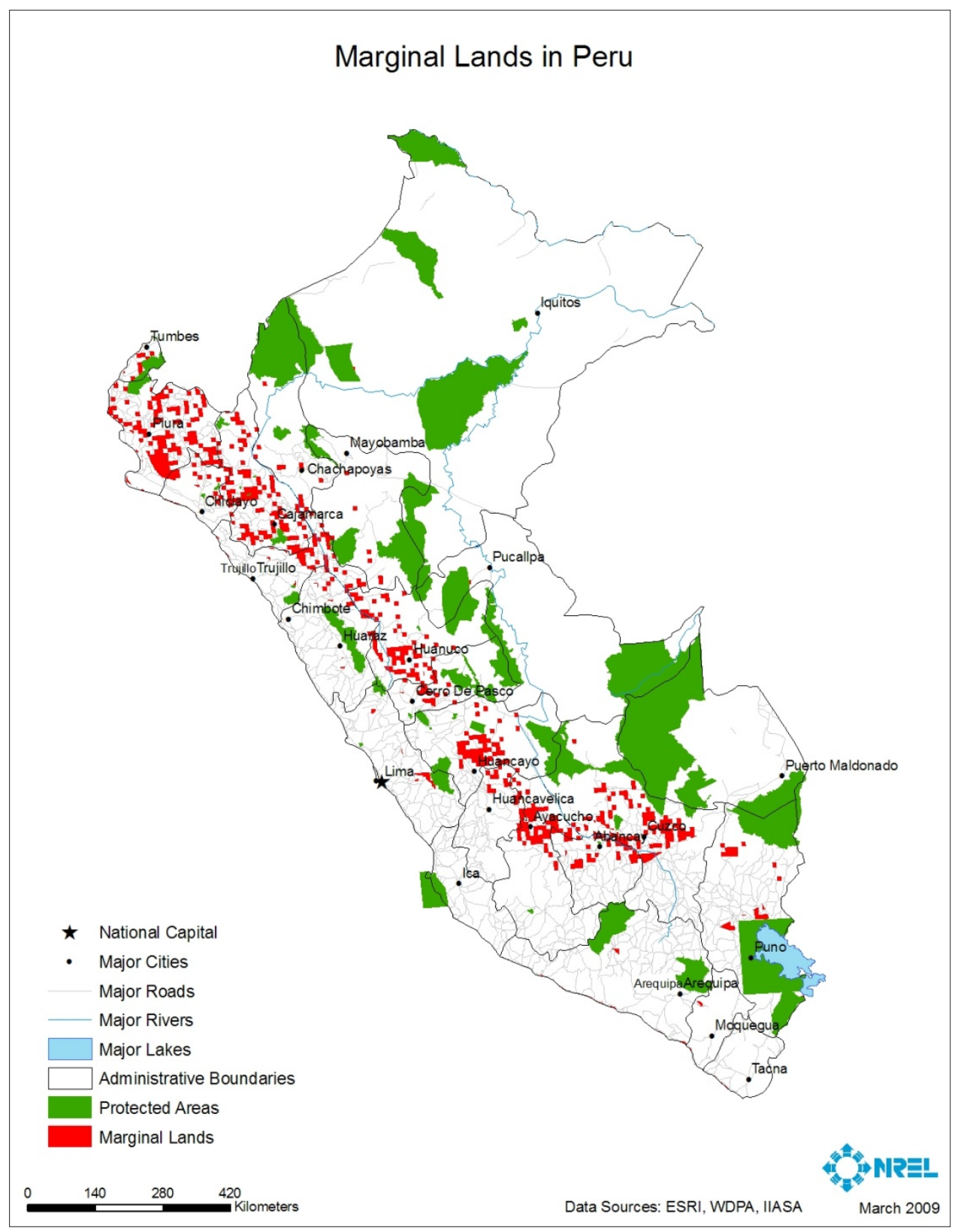

Figure 17 Marginal Lands in Peru 
Total land area $-280,958 \mathrm{~km}^{2}$

Population - 91,077,287

Marginal lands $-6,357 \mathrm{~km}^{2}$ (2.3\% of total area)

Biomass resource potential on marginal lands - 1,793,000 tonnes/year

Ethanol potential from marginal lands $-0.7 \mathrm{hm}^{3}$ (13\% of current gasoline consumption)

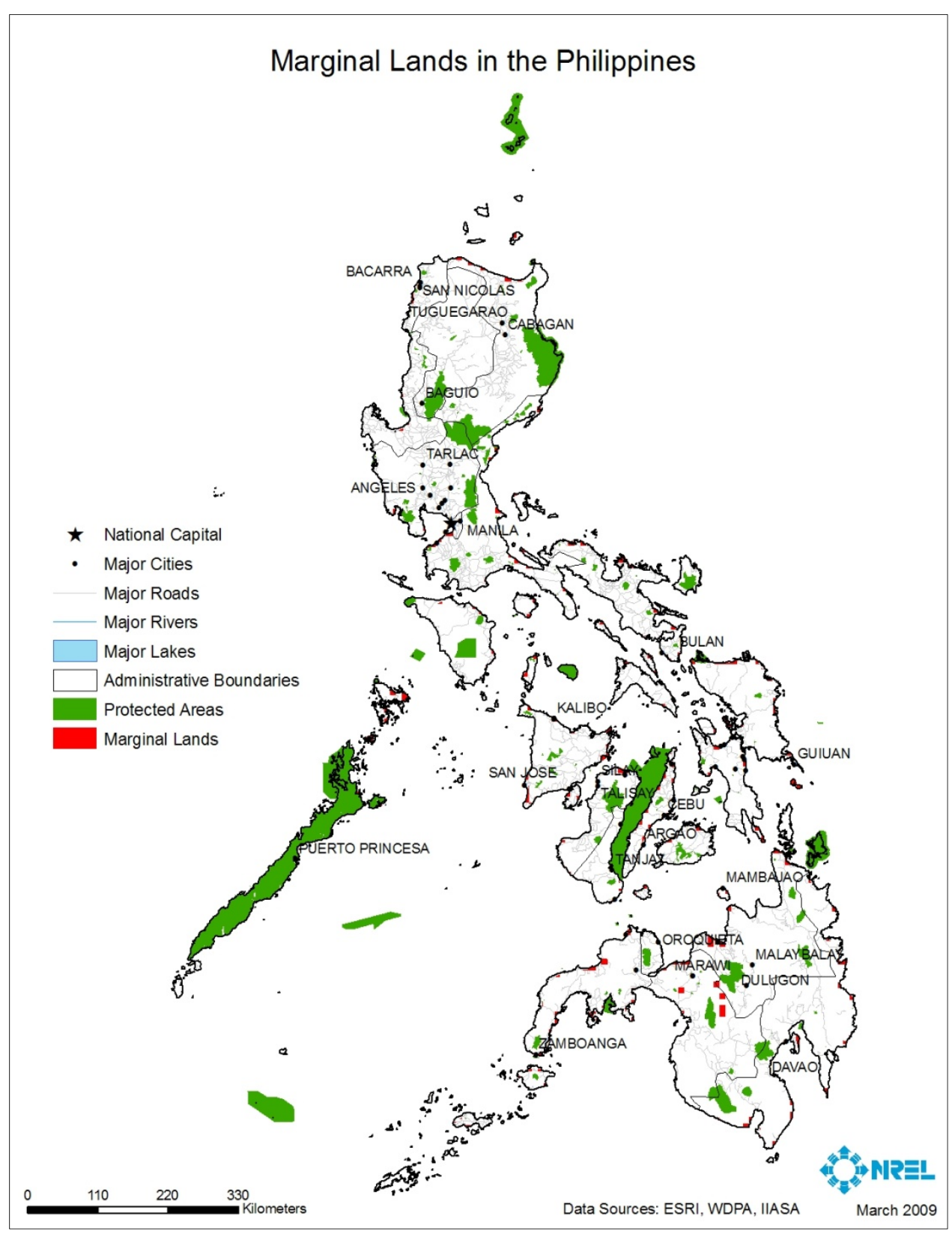

Figure 18 Marginal Lands in the Philippines 


\section{Russia}

Total land area - 16,897,294 $\mathrm{km}^{2}$

Population - 141,377,752

Marginal lands $-369,176 \mathrm{~km}^{2}(2.2 \%$ of total area)

Biomass resource potential on marginal lands $-154,412,000$ tonnes/year

Ethanol potential from marginal lands $-61 \mathrm{hm}^{3}$ (105\% of current gasoline consumption)

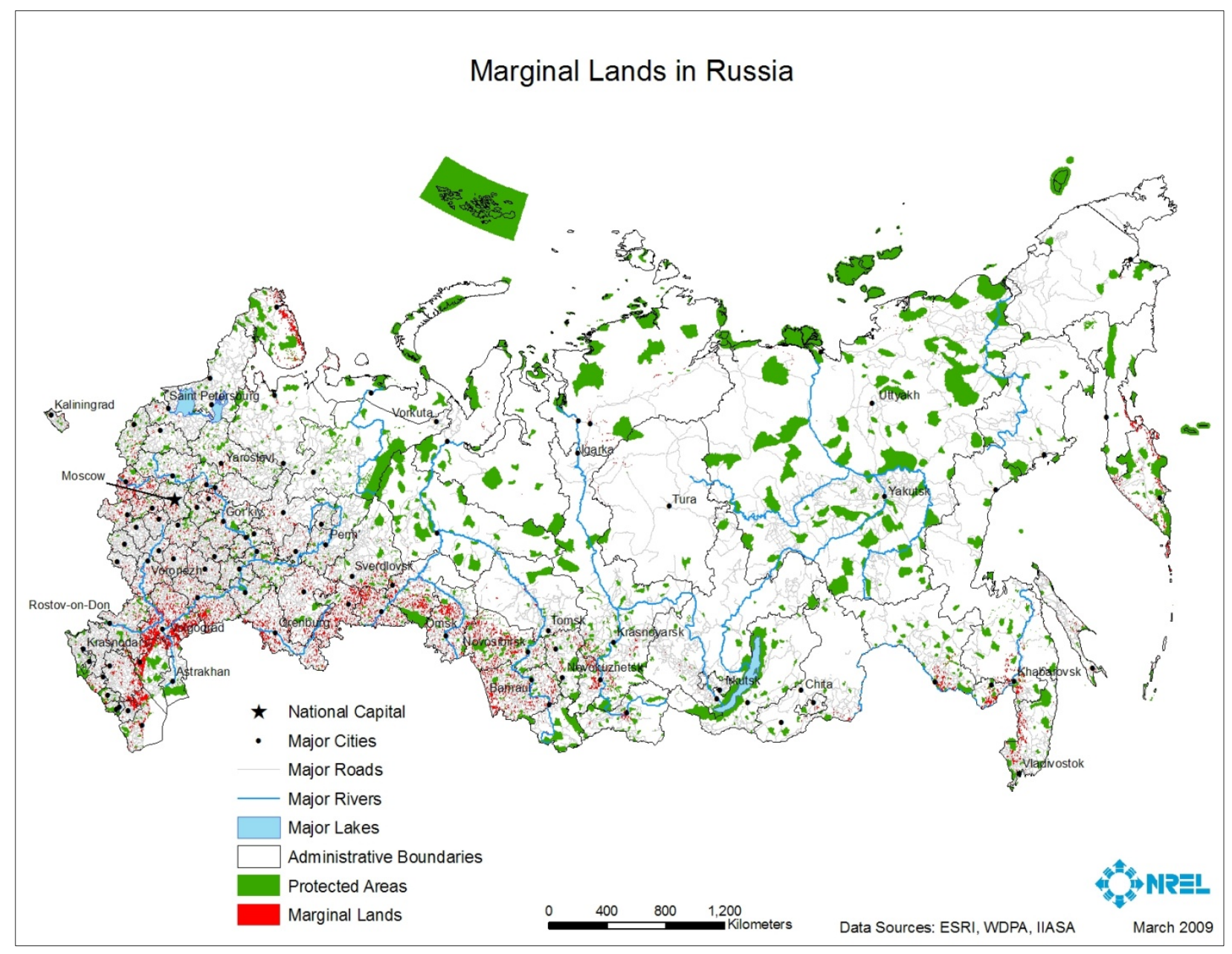

Figure 19 Marginal Lands in Russia 
Total land area $-35,980 \mathrm{~km}^{2}$

Population - 22,858,872

Marginal lands $-693 \mathrm{~km}^{2}$ (2\% of total area)

Biomass resource potential on marginal lands $-558,000$ tonnes/year

Ethanol potential from marginal lands $-0.2 \mathrm{hm}^{3}$ ( $1.3 \%$ of current gasoline consumption)

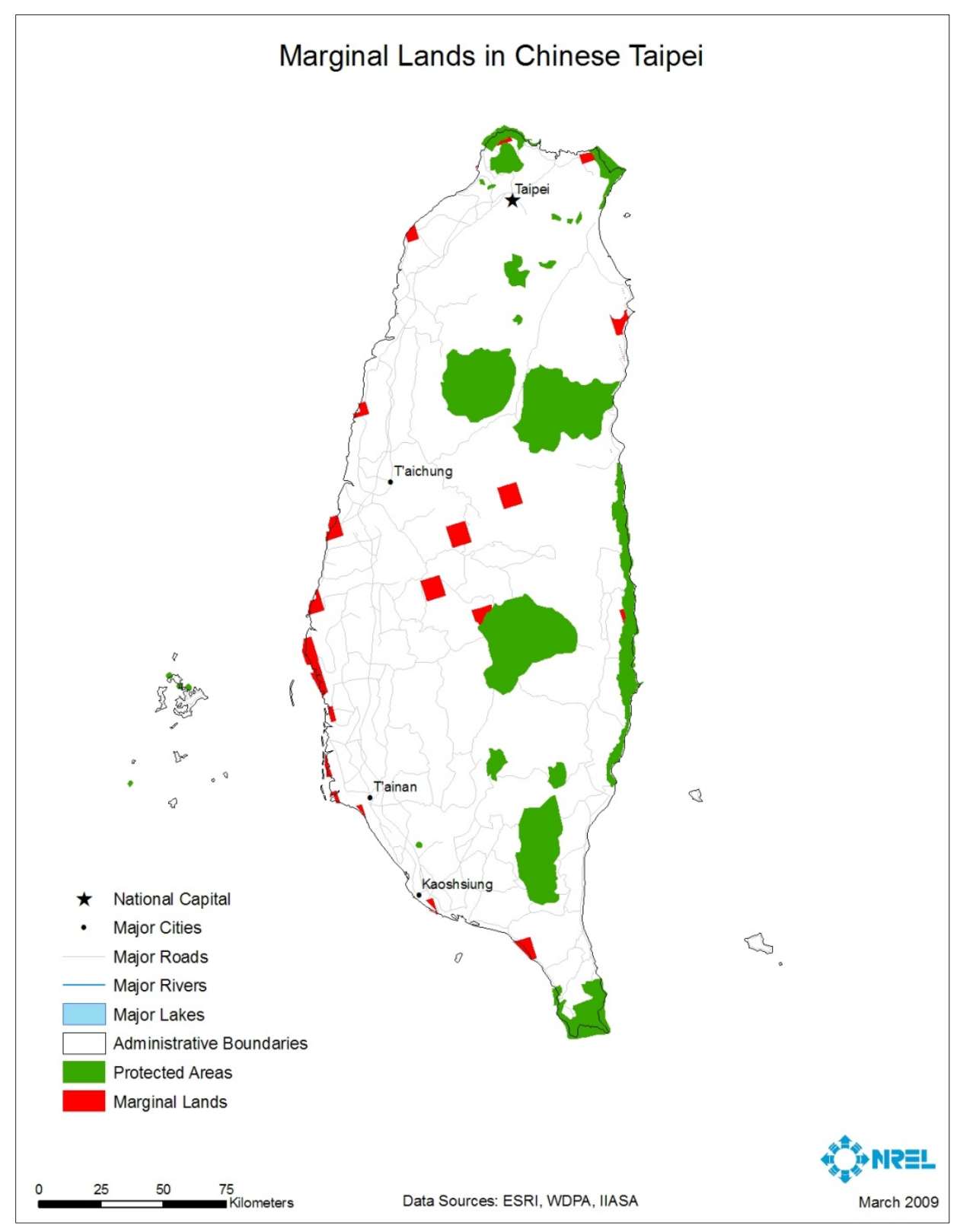

Figure 20 Marginal Lands in Chinese Taipei 
Total land area $-515,357 \mathrm{~km}^{2}$

Population - 65,068,149

Marginal lands $-17,253 \mathrm{~km}^{2}$ (3.3\% of total area)

Biomass resource potential on marginal lands $-10,394,000$ tonnes/year

Ethanol potential from marginal lands $-4 \mathrm{hm}^{3}$ (38\% of current gasoline consumption)

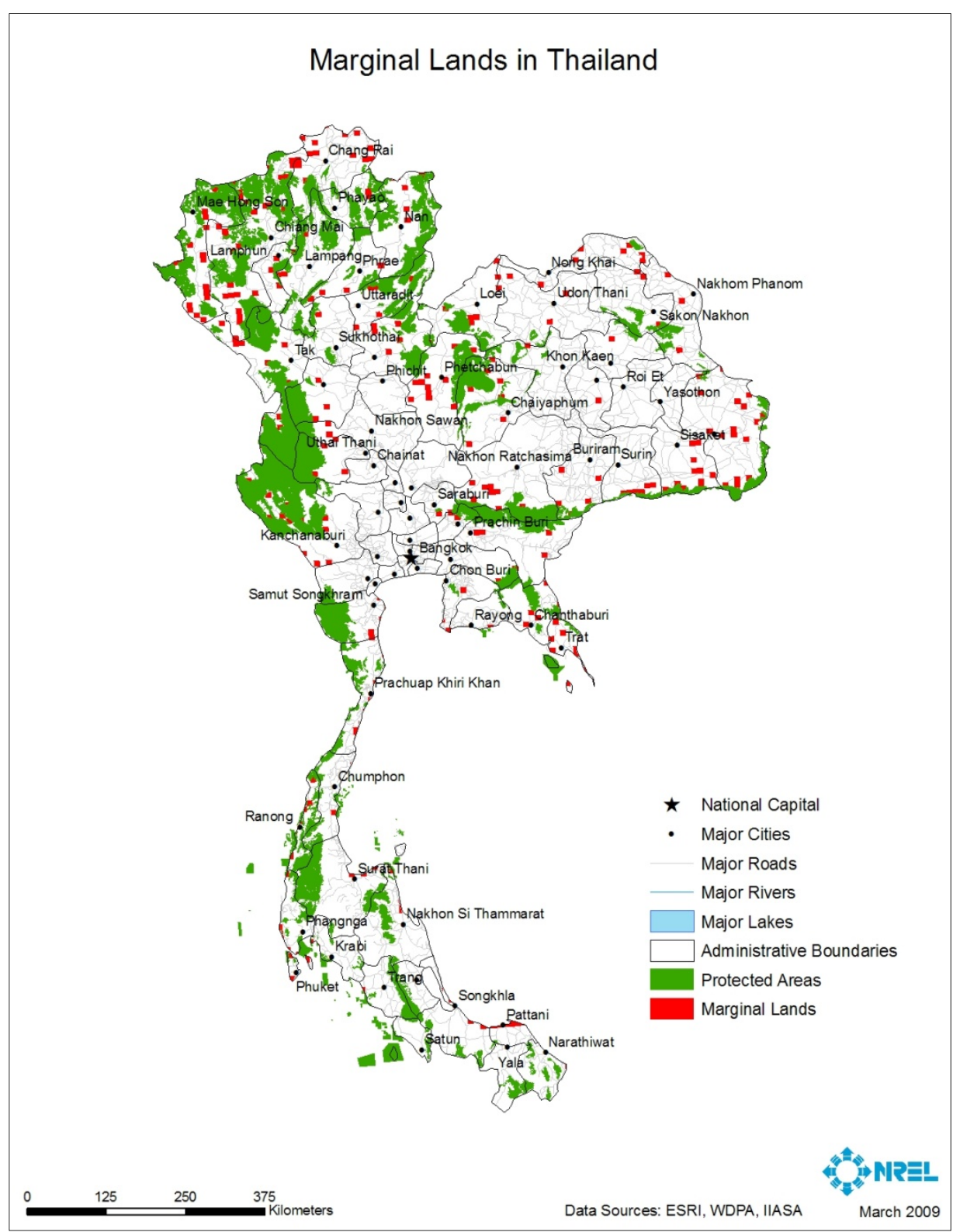

Figure 21 Marginal Lands in Thailand 
Total land area $-9,426,295 \mathrm{~km}^{2}$

Population - 301,139,947

Marginal lands $-1,214,007 \mathrm{~km}^{2}$ ( $13 \%$ of total area)

Biomass resource potential on marginal lands $-377,413,000$ tonnes/year

Ethanol potential from marginal lands $-148 \mathrm{hm}^{3}$ (19\% of current gasoline consumption)

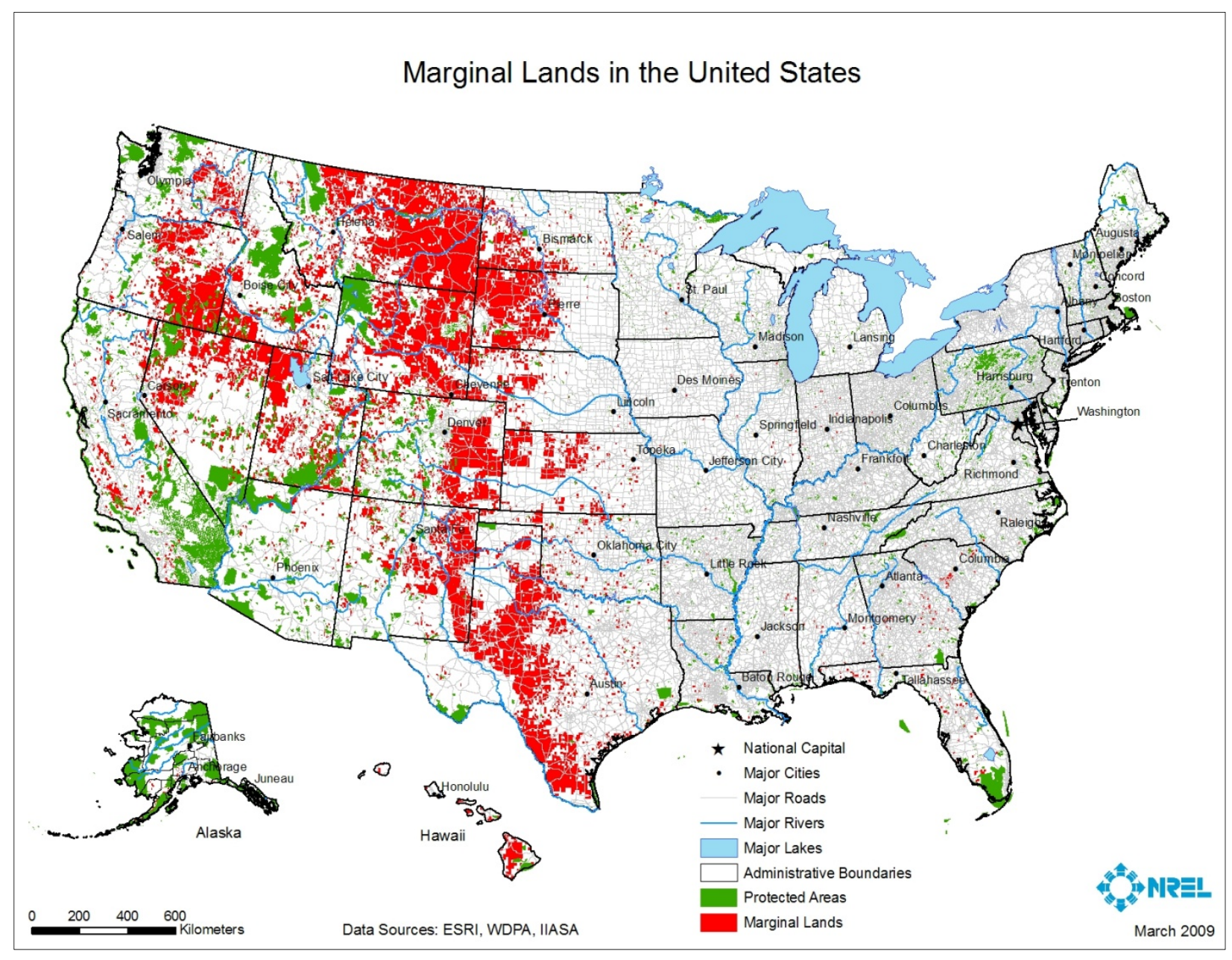

Figure 22 Marginal Lands in the United States 
Total land area $-322,743 \mathrm{~km}^{2}$

Population - 85,262,356

Marginal lands $-21,090 \mathrm{~km}^{2}(6.5 \%$ of total area)

Biomass resource potential on marginal lands $-11,281,000$ tonnes/year

Ethanol potential from marginal lands $-4.4 \mathrm{hm}^{3}$ (79\% of current gasoline consumption)

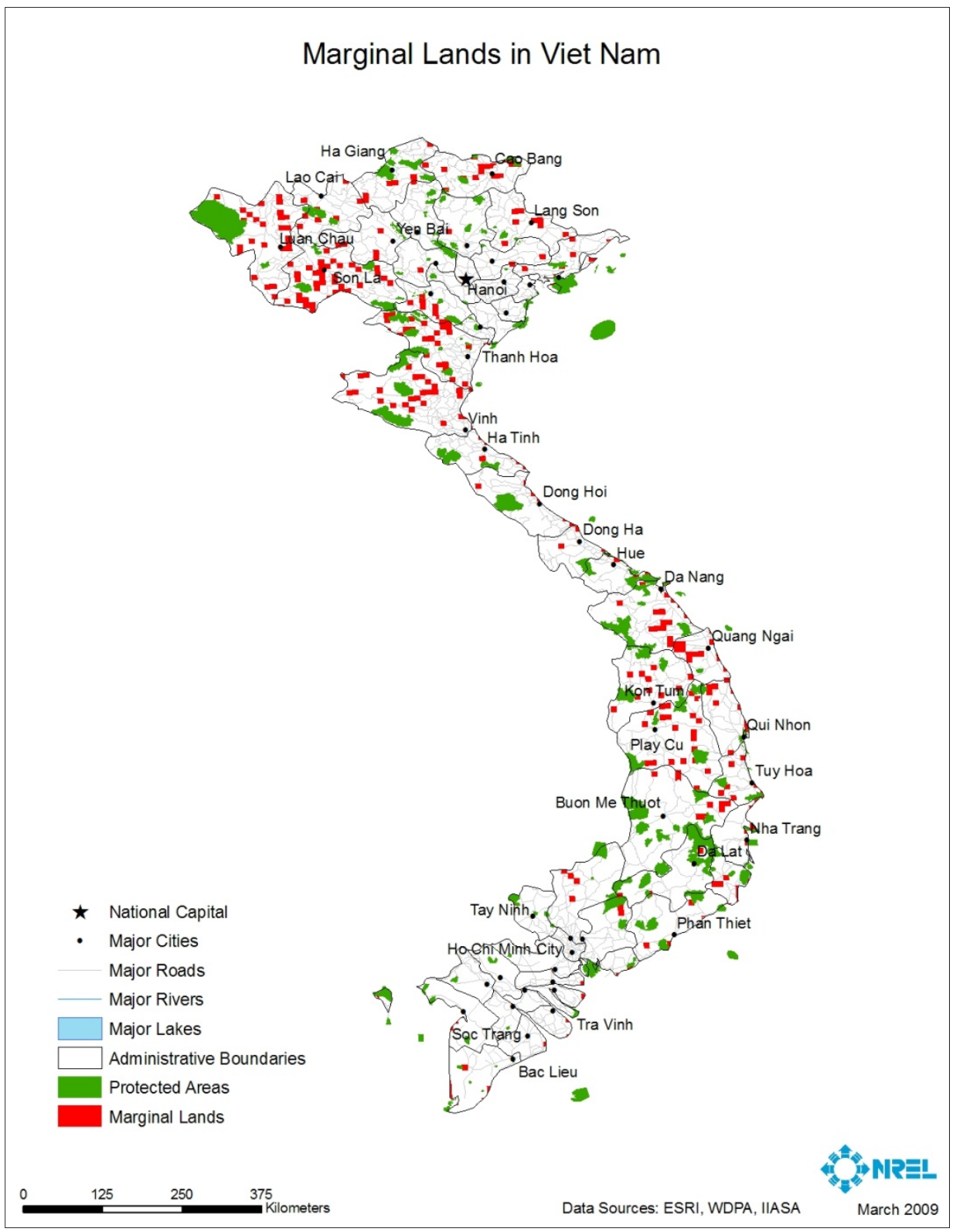

Figure 23 Marginal Lands in Viet Nam 
Prepared By:

Anelia Milbrandt

National Renewable Energy Laboratory (NREL)

1617 Cole Blvd

Golden, Colorado, USA 80401

Phone: (303) 275-3000

Website: www.nrel.gov

Dr. Ralph P. Overend

NREL Research Fellow (Retired)

Ottawa, Ontario, Canada

Produced for:

APEC Secretariat

35 Heng Mui Keng Terrace Singapore 119616

Tel: (65) 68919-600 Fax: (65) 68919-690

Email: info@apec.org Website: www.apec.org

(C) 2008 APEC Secretariat

APEC\#209-RE-01.4 